1 Title: Nitrous oxide and methane in Atlantic and Mediterranean waters in the Strait of

2 Gibraltar: air-sea fluxes and inter-basin exchange.

3

4

5 Authors: de la Paz, $M^{1,2}$., I.E.Huertas ${ }^{1}$, S. Flecha ${ }^{1}$, A.F. Ríos ${ }^{2}$ and F.F. Pérez ${ }^{2}$.

6 (1) Instituto de Ciencias Marinas de Andalucía, CSIC, Campus Universitario Río San Pedro 7 s/n, E-11519 Puerto Real, Spain

8 (2) Instituto de Investigaciones Marinas, CSIC, Eduardo Cabello 6, E-36208 Vigo, Spain

*Corresponding author: Mercedes de la Paz, phone +34 956832612

E-mail: mercedes.delapaz@iim.csic.es

\title{
Highlights
}

- N2O distribution follows the two layers scheme circulation in the Strait of Gibraltar.

- Mediterranean deep waters are highly undersaturated in $\mathrm{CH} 4$.

- Nitrification acts as the main N2O source in the Mediterranean overflow water.

- Temperature controls the seasonal variability of $\mathrm{N} 2 \mathrm{O}$ in the upper layer.

- The outflow of Mediterranean waters supplies N2O to the North Atlantic. 
Abstract:

The global ocean plays an important role in the overall budget of nitrous oxide $\left(\mathrm{N}_{2} \mathrm{O}\right)$ and methane $\left(\mathrm{CH}_{4}\right)$, as both gases are produced within the ocean and released to the atmosphere. However, for large parts of the open and coastal oceans there is little or no spatial data coverage for $\mathrm{N}_{2} \mathrm{O}$ and $\mathrm{CH}_{4}$. Hence, a better assessment of marine emissions estimates is necessary. As a contribution to remedying the scarcity of data on marine regions, $\mathrm{N}_{2} \mathrm{O}$ and $\mathrm{CH}_{4}$ concentrations have been determined in the Strait of Gibraltar at the ocean Fixed Time series (GIFT). During six cruises performed between July 2011 and November 2014 samples were collected at the surface and various depths in the water column, and subsequently measured using Gas Chromatography. From this we were able to quantify the temporal variability of the gas air-sea exchange in the area and examine the vertical distribution of $\mathrm{N}_{2} \mathrm{O}$ and $\mathrm{CH}_{4}$ in Atlantic and Mediterranean waters. Results show that surface Atlantic waters are nearly in equilibrium with the atmosphere whereas deeper Mediterranean waters are oversaturated in $\mathrm{N}_{2} \mathrm{O}$, and a gradient that gradually increases with depth was detected in the water column. Temperature was found to be the main factor responsible for the seasonal variability of $\mathrm{N}_{2} \mathrm{O}$ in the surface layer. Furthermore, although $\mathrm{CH}_{4}$ levels did not reveal any feature clearly associated with the circulation of water masses, vertical distributions showed that higher concentrations are generally observed in the Atlantic layer, and that the deeper Mediterranean waters are considerably undersaturated (by up to 50\%). Even though surface waters act as a source of atmospheric $\mathrm{N}_{2} \mathrm{O}$ during certain periods, on an annual basis the net $\mathrm{N}_{2} \mathrm{O}$ flux in the Strait of Gibraltar is only $0.35 \pm 0.27 \mu \mathrm{mol} \mathrm{m}^{-2} \mathrm{~d}^{-1}$, meaning that these waters are almost in a neutral status with respect to the atmosphere. Seasonally, the region behaves as a slight sink for atmospheric $\mathrm{CH}_{4}$ in winter and as a source in spring and fall. Approximating the circulation pattern in the Strait to a bi-layer scheme, $\mathrm{N}_{2} \mathrm{O}$ exchange between basins was also calculated, and a net export from the Mediterranean Sea to the Atlantic Ocean equivalent to $39 \mu \mathrm{mol} \mathrm{m}^{-2} \mathrm{~d}^{-1}$ was found 
1. Introduction:

73 The global ocean contributes markedly to the overall budget of radiatively-active non- $\mathrm{CO}_{2}$ gases such as nitrous oxide $\left(\mathrm{N}_{2} \mathrm{O}\right)$ and, to a lesser extent, methane $\left(\mathrm{CH}_{4}\right)$; this is because both gases are produced in the marine domain and released to the atmosphere, where they contribute to the greenhouse effect and participate in tropospheric and stratospheric chemical cycling (Crutzen, 1970; 1991). The ocean budgets for $\mathrm{N}_{2} \mathrm{O}$ and $\mathrm{CH}_{4}$ are climate-sensitive, although there are fewer field observations and less understanding of their biogeochemical cycles, in comparison with $\mathrm{CO}_{2}$ (Garcon et al., 2014). A better assessment of the present oceanic inventories of these greenhouse gases is necessary in order to provide realistic and accurate inputs to predictive models under future climate change scenarios. Improved database is required particularly in the case of $\mathrm{N}_{2} \mathrm{O}$ because, according to the IPCC 5th Assessment Report

83 (Ciais et al., 2013), the oceans in total behave as a major natural $\mathrm{N}_{2} \mathrm{O}$ source that releases 3.8

$84 \mathrm{Tg}-\mathrm{N} \cdot$ year $^{-1}$ to the atmosphere. Similarly, estuaries, rivers and streams emit anthropogenic $\mathrm{N}_{2} \mathrm{O}$, 85 and together release $0.6 \mathrm{Tg}-\mathrm{N} \cdot$ year $^{-1}$ (Ciais et al., 2013). These two water sources contribute $20 \%$ and $3 \%$ respectively to the total global $\mathrm{N}_{2} \mathrm{O}$ emissions. Nevertheless, as stated by some authors (Nevison et al., 1995; 2003; Rhee et al., 2009; Bakker et al., 2013), considerable uncertainties arise over these estimates, particularly in coastal areas (upwelling regions, continental shelves, estuaries and mangroves) due to the reduced amount and quality of data currently available. In addition, ocean measurements are also biased to the summer season (Bange et al., 2009), which can lead to an overestimation of the dissolved $\mathrm{N}_{2} \mathrm{O}$ concentration when computations are extrapolated to longer timescales. In marine environments $\mathrm{N}_{2} \mathrm{O}$ is produced mainly by two microbial pathways: first, as a by-product during nitrification (conversion of ammonia, $\mathrm{NH}_{4}{ }^{+}$, into nitrate, $\mathrm{NO}_{3}{ }^{-}$) and second, as an intermediate during denitrification (conversion of $\mathrm{NO}_{3}{ }^{-}$to dinitrogen, $\mathrm{N}_{2}$ ). The presence of the microorganisms that mediate each pathway, and the corresponding $\mathrm{N}_{2} \mathrm{O}$ yields, are highly dependent on the concentration of dissolved oxygen $\left(\mathrm{O}_{2}\right)$ (e.g., Goreau et al., 1980; Codispoti et al., 2005). Nitrification is one of 
the processes involved in the aerobic remineralization of organic matter; hence under oxic conditions, as found nearly everywhere in the global ocean, $\mathrm{N}_{2} \mathrm{O}$ is formed mainly via

100 nitrification, whereas suboxic to anoxic conditions that favour the net formation of $\mathrm{N}_{2} \mathrm{O}$ via 101 denitrification are found only in about $0.1-0.2 \%$ of total ocean volume (Codispoti, 2010; Freing et 102 al., 2012).

103 In contrast to $\mathrm{N}_{2} \mathrm{O}$, the contribution of oceanic $\mathrm{CH}_{4}$ to the global tropospheric $\mathrm{CH}_{4}$ budget is 104 relatively minor: marine $\mathrm{CH}_{4}$ emissions represent only a small net input (Ciais et al., 2013). 105 Methane measurements in sediments, where concentrations are in the millimolar scale, were 106 first reported in the mid-1950s, while $\mathrm{CH}_{4}$ generation in ocean waters was discovered in the late 107 1960s, in part due to measurement constraints as marine $\mathrm{CH}_{4}$ levels rarely exceed nanomolar 108 levels (Reeburgh, 2007). Since then, even though significant efforts have been made to quantify 109 marine-derived $\mathrm{CH}_{4}$, the global ocean $\mathrm{CH}_{4}$ dataset is still quite limited (Bange et al., 2009).

110 Biological production of methane or methanogenesis is the last step in the remineralization of 111 complex organic matter in anaerobic systems and, unlike $\mathrm{N}_{2} \mathrm{O}$, this mechanism requires strictly 112 anaerobic conditions. $\mathrm{CH}_{4}$ is produced in anoxic sediments, or in the water column via 113 methanogenic bacteria found in sinking particulate matter and in zooplankton fecal pellets (e.g.,

114 De Angelis and Lee, 1994; Karl and Tilbrook, 1994). On the other hand, $\mathrm{CH}_{4}$ can be consumed 115 via aerobic and anaerobic oxidation occurring in the water column and sediments (e.g. Scranton 116 and Brewer, 1977; Boetius et al., 2000). Nevertheless, although $\mathrm{CH}_{4}$ concentrations in the open 117 ocean are generally rather low, it has been found that net $\mathrm{CH}_{4}$ production in the mixed layer 118 leads generally to supersaturation in $\mathrm{O}_{2}$-saturated near-surface waters, with typical values of 119 130-160\%, a phenomenon known as the marine $\mathrm{CH}_{4}$ paradox (Reeburgh, 2007). The role of 120 phosphate limitation has only recently been discussed as a possible regulator of methane 121 production in oxygenated waters (Karl et al., 2008; Carini et al., 2014). Apparently, under 122 phosphorous limitation, microorganisms increase their consumption of organic phosphorus 123 compounds, such as exogenous methyl phosphonate, that can be converted to methane, as 124 has been demonstrated experimentally (Karl et al., 2008; Carini et al., 2014). Below the ocean 125 mixed layer and away from the oxygen minimum zones, $\mathrm{CH}_{4}$ concentrations progressively 126 decrease with depth through oxidation, even reaching undetectable levels (Bakker et al., 2013). 
127 Monitoring of both $\mathrm{N}_{2} \mathrm{O}$ and $\mathrm{CH}_{4}$ is then crucial for deciphering the feedbacks between gas

128 formation and emissions, and short- and long-term environmental repercussions.

129 Currently, these trace gases are measured regularly only at a few time-series sites, such as 130 Station Aloha (Hawaii), CaTS (off Goa, India), Line P (North Pacific), Bocknis Eck (Baltic Sea) 131 and off Chile (Dore et al., 1998; Bange et al., 2010; Naqvi et al., 2010). Assessment of $\mathrm{N}_{2} \mathrm{O}$ and

$132 \mathrm{CH}_{4}$ has recently been incorporated in the regular measurements taken at the Gibraltar Fixed

133 Time series (GIFT) station, located in the Strait of Gibraltar, which connects the Mediterranean

134 Sea and Atlantic Ocean. Data from the GIFT series have been used to estimate biogeochemical

135 fluxes between the two basins (Huertas et al., 2009; de la Paz et al., 2011; Huertas et al., 136 2012). The exchange of waters masses through the Strait has a strong influence on the general 137 circulation of the Mediterranean and North Atlantic (Peliz et al., 2009); it also regulates the 138 inventories of many chemical compounds in both regions, as is the case of carbon (Álvarez et 139 al., 2005; Flecha et al., 2012), nutrients (Dafner et al., 2003; Bethoux et al., 2005; Huertas et al., 140 2012), organic matter (Dafner et al., 2001), hydrocarbons (Dachs et al., 1997), trace metals 141 (Van Geen and Boyle, 1990; Elbaz-Poulichet et al., 2001) and radionuclides (Schmidt, 2006; 142 Periáñez, 2008). Therefore, because of its strategic position linking two different marine 143 eco-regions and its role as a sensor for climate change in the Mediterranean (Schroeder et al., 144 2012), the Strait of Gibraltar represents a node where $\mathrm{N}_{2} \mathrm{O}$ and $\mathrm{CH}_{4}$ monitoring is of particular 145 interest and where no previous measurements have been performed to date. In addition, since 146 complementary biogeochemical and physical parameters are being regularly scrutinized at the

147 GIFT station, our understanding of the processes affecting the distribution of both gases in the 148 region and their transport between the two adjacent basins can be facilitated.

149 This work provides $\mathrm{N}_{2} \mathrm{O}$ and $\mathrm{CH}_{4}$ data collected for the first time at the surface and in the water 150 column in the Strait of Gibraltar. The aim of our study has been to evaluate the role of this 151 region as a sink or a source of these two gases to the atmosphere by quantifying the air-sea 152 exchange and its temporal variability. Furthermore, the signature of the two trace gases in the 153 inflowing Atlantic and outflowing Mediterranean waters has been analysed, with the $\mathrm{N}_{2} \mathrm{O}$ 154 exchange between the two basins also being computed and used to propose a regional balance 155 that considers advected and atmospheric fluxes of this compound. Biogeochemical processes 156 responsible for the spatio-temporal distribution of $\mathrm{N}_{2} \mathrm{O}$ and $\mathrm{CH}_{4}$ in the region are also discussed. 
2.1. Study site:

The Strait of Gibraltar is located at the south of the Iberian Peninsula and is the only connection between the Mediterranean Sea and the Atlantic Ocean. It is an east-west orientated channel of a minimum width of $14 \mathrm{~km}$ at the Tarifa Narrows (see Figure 1). Circulation in the Strait can be approximated as a bi-layer system formed by the eastward surface Atlantic inflow water (AIW) and the deep westward outflow of saltier Mediterranean Outflow water (MOW), although many physical phenomena occurring at several temporal scales are superimposed over this simple scheme, affecting the magnitude of both flows. The AIW composition is mainly the result of the mixing of the North Atlantic Central Water (NACW, salinity less than 36.06) and a warmer modified form of NACW. For the purposes of this study, the latter will be referred to as Surface Atlantic Water (SAW, salinity about of 36.46) (Gascard and Richez, 1985). Spanish Shelf Water (SSW) and other constituents also influence the composition of the SAW (Van Geen and Boyle, 1990). Similarly, the MOW (salinity $38.2-38.5$ and temperature $13-13.5{ }^{\circ} \mathrm{C}$ ) is a mixture of

174 Mediterranean intermediate and deep waters, such as the Levantine Intermediate Water (LIW)

175 whose origin is in the eastern basin and which subsequently flows across the Strait of Sicily to 176 join the western Mediterranean and the Western Mediterranean Deep Water (WMDW) formed

177 in the Gulf of Lions. The analysis presented here will focus on the main water masses (SAW,

178 NACW and MOW) comprising the two layers; the remaining constituents of flows are not 179 included explicitly since discrimination between LIW and WMDW requires a very high (almost 180 continuous) sampling frequency, and the contribution of SSW to SAW is minor and intermittent 181 (Bray et al., 1995).

182 The bottom topography of the Strait is characterized by a main sill on the western side (the 183 Camarinal Sill), which lifts the seabed from a depth of nearly $900 \mathrm{~m}$ to a depth of only $\sim 300 \mathrm{~m}$.

184 The interaction between tides and the sharp topography of the channel generate a very 185 complicated hydrodynamic pattern in which undulatory features occur at the AtlanticMediterranean Interface (AMI), such as internal bores (Boyce, 1975; Armi and Farmer, 1985), 
187 internal waves (Bruno et al., 2002), and horizontal surface divergences. As a result, the 188 Mediterranean outflow entrains the upper Atlantic layer. Therefore, bathymetry, together with 189 meteorological forcing, induces modifications to the two-layer average circulation scheme, with 190 the intensity of the mechanism varying on the tidal to subinertial scale (Garcia-Lafuente et al., 191 2002).

192 The intense hydrodynamic regime of the Strait has been described as the main forcing agent for 193 the distribution and dynamics of biogeochemical variables in this area. In fact, if hydrodynamic 194 processes were excluded, and only in situ biological processes were taken into account, the 195 biogeochemical patterns observed in the AIW could not be explained (e.g., Echevarría et al., 196 2002; Macías et al., 2008). This local hydrodynamic control over biogeochemistry may even be 197 extended to a larger spatial scale, as has been shown recently in the Western Mediterranean by 198 Naranjo et al. (2014).

\subsection{Methods}

201

\subsubsection{Field sampling and analysis}

203 The GIFT time series established in 2005 is formed by 3 stations distributed along the east-west axis of the Strait (Figure 1), where discrete samples are periodically collected at a minimum of 5 depth levels. Sampling strategy is aimed at resolving the spatial distribution of biogeochemical variables within the different water bodies that can be differentiated in the Strait and whose positions change both on the vertical scale and longitudinally. Since July $2011, \mathrm{~N}_{2} \mathrm{O}$ and $\mathrm{CH}_{4}$ measurements have been added to the set of properties that are routinely studied in the area.

209 This work analyses data collected from that date until November 2014, a period during which 6 campaigns were carried out (Table 1). Due to analytical failure, $\mathrm{CH}_{4}$ results are only available

211 from February 2012. At each station, a temperature and salinity profile was obtained with a

212 SeaBird 911 Plus CTD Probe, which was followed by water sampling with Niskin bottles. Depths

213 were selected on board depending on the position of the AMI at that instant; this position was

214 given by the CTD casts. The uppermost samples were collected at $5 \mathrm{~m}$ and the depth of the 215 deepest samples varied with bathymetry, with the deepest level, $860 \mathrm{~m}$, being located at Station

216 3. Discrete samples at each level were taken, in this order, for dissolved Oxygen $\left(\mathrm{O}_{2}\right), \mathrm{N}_{2} \mathrm{O}, \mathrm{CH}_{4}$ 
217 and nitrate. For $\mathrm{N}_{2} \mathrm{O}$ and $\mathrm{CH}_{4}$ two replicates were collected using $120 \mathrm{~mL}$ serum vials, sealed 218 with grey-butyl rubber septa and aluminum crimps. Samples were preserved with $250 \mu \mathrm{L}$ of 219 saturated $\mathrm{HgCl}_{2}$ to inhibit microbial activity. Trace gas samples were stored upside down in the 220 dark, for a maximum of six months, until analysis in the laboratory. Dissolved $\mathrm{N}_{2} \mathrm{O}$ and $\mathrm{CH}_{4}$ 221 were subsequently analyzed by static-headspace equilibration gas chromatography (GC). The analytical equipment is an Agilent 7890 GC with an electron capture detector (ECD) for $\mathrm{N}_{2} \mathrm{O}$

223 and flame ionization detector (FID) for $\mathrm{CH}_{4}$. The homemade device used for the creation and 224 injection of the headspace in the GC is inspired by the technique developed by Neill et al. 225 (1997) for $\mathrm{CO}_{2}$ chromatographic analysis, in which $19.7 \mathrm{~mL}$ of sample are replaced with a gas of known $\mathrm{N}_{2} \mathrm{O}$ and $\mathrm{CH}_{4}$ composition using a high precision automatic burette (Dosimat 665,

227 Metrohm). The headspace gas is stored in a $5 \mathrm{~L}$ Tedlar gas-bag before the injection, to ensure that headspace gas is introduced at atmospheric pressure. Following equilibration after a minimum of 12 hours, $18.5 \mathrm{~mL}$ of headspace is flushed into the two connected GC sample 230 loops, while introducing a dense brine solution into the bottom of the sample bottle. Then, $\mathrm{N}_{2} \mathrm{O}$ 231 and $\mathrm{CH}_{4}$ are chromatographically separated using two independent Porapak $\mathrm{Q}$ packed columns 232 (80-100 mesh; $3 \mathrm{~m}$ length for $\mathrm{N}_{2} \mathrm{O}$ and $1.5 \mathrm{~m}$ for $\mathrm{CH}_{4}$ ) operated at $60{ }^{\circ} \mathrm{C}$ and detected with the 233 ECD and FID, respectively. Both separations use ultrahigh purity $\mathrm{N}_{2}$ as carrier gas (AirLiquide, 234 purity $99.9999 \%$ ) and, because water vapor and $\mathrm{CO}_{2}$ interfere in the $\mathrm{N}_{2} \mathrm{O}$ analysis, both are 235 eliminated using magnesium perchlorate and Carbosorb ${ }^{\circledR}$ traps located before the packed 236 columns. The system was calibrated using three standard gas mixtures of different origin: a 237 certified NOAA primary standard with composition similar to atmosphere $(324.97 \pm 0.13 \mathrm{ppb}$ for $238 \mathrm{~N}_{2} \mathrm{O}$ and $1863.4 \pm 0.3 \mathrm{ppb}$ for $\mathrm{CH}_{4}$ ), a second standard gas mixture provided by AirLiquide 239 (France) with certified concentration (1020 ppb for $\mathrm{N}_{2} \mathrm{O}$ and $3000 \mathrm{ppb}$ for $\mathrm{CH}_{4}$ ) and a secondary 240 standard calibrated against NOAA primary standard (104 ppb for $\mathrm{N}_{2} \mathrm{O}$ and $2462 \mathrm{ppb}$ for $\mathrm{CH}_{4}$ ) 241 measured routinely every 4 samples to check the GC stability. The precision of the method 242 estimated from the coefficient of variation based on replicate analysis of water samples $(n=10)$ 243 was $0.6 \%$ for $\mathrm{CH}_{4}$ and $0.4 \%$ for $\mathrm{N}_{2} \mathrm{O}$. The equilibrated mixing ratios corrected for phase 244 partitioning during analysis were computed following Upstill-Goddard et al. (1996). Dissolved 245 concentrations were determined by applying the expressions for solubility proposed by Weiss 246 and Price (1980) and Weisenburg and Guinasso (1979) for $\mathrm{N}_{2} \mathrm{O}$ and $\mathrm{CH}_{4}$, respectively. 
$247 \mathrm{O}_{2}$ samples were taken in a sealed glass flask and stored in darkness for $24 \mathrm{~h}$, as described by 248 the Winkler method, for later analysis by potentiometric titration (Metrohm 794 Titroprocessor),

249 with an estimated uncertainty of $\pm 1 \mu \mathrm{mol} \mathrm{kg}{ }^{-1}$.

250 For nitrate, three replicates of $12 \mathrm{~mL}$ of filtered seawater (Whatman GF/F filters) were taken

251 from the Niskin bottle and stored at $-20^{\circ} \mathrm{C}$. Concentration of nitrate was measured in the 252 laboratory using a TRAACS800 (Bran+Luebbe) auto-analyzer and the techniques of Grasshoff 253 et al. (1983). The standard deviation for the mean of all replicates was $0.06 \mu \mathrm{mol} \mathrm{kg}^{-1}$ for nitrate.

\section{2.2.2. Calculations}

256 The saturation values of $\mathrm{O}_{2}$ were calculated with the equation given by Benson and Krause 257 (UNESCO, 1986) and the Apparent Oxygen Utilization (AOU) was defined as the difference 258 between the oxygen concentration at saturation and the observed oxygen concentration.

259 Apparent $\mathrm{N}_{2} \mathrm{O}$ production was calculated as the difference between the observed $\mathrm{N}_{2} \mathrm{O}$ 260 concentration and the expected $\mathrm{N}_{2} \mathrm{O}$ concentration in the equilibrium at the corresponding 261 temperature (Yoshinari, 1976), in a similar way to the AOU concept, hence:

263 Saturation values expressed as percentage (\%) for $\mathrm{N}_{2} \mathrm{O}$ and $\mathrm{CH}_{4}$ were computed as the ratio 264 between the gas concentration measured and the calculated equilibrium concentration for $\mathrm{N}_{2} \mathrm{O}$ 265 and $\mathrm{CH}_{4}$. On the one hand, the calculations of the equilibrium concentrations in the entire water 266 column (deeper than $25 \mathrm{~m}$ ) were done using the mean global atmospheric ratios for the study 267 period (2011-2014) in order to obtain a homogeneous long-term vertical signal for the $\mathrm{N}_{2} \mathrm{O}$ and $268 \mathrm{CH}_{4}$ saturation values. These atmospheric mixing ratios for $\mathrm{N}_{2} \mathrm{O}\left(\mathrm{xN}_{2} \mathrm{O}_{\text {atm }}\right)$ and $\mathrm{CH}_{4}\left(\mathrm{xCH}_{4 a t m}\right)$ 269 were provided by the World Data Center for Greenhouse Gases

270 (http://ds.data.jma.go.jp/gmd/wdcgg/). Such mean values were calculated as $325 \mathrm{ppb}$ and 1818 $271 \mathrm{ppb}$ for $\mathrm{xN}_{2} \mathrm{O}_{\text {atm }}$ and $\mathrm{xCH}_{4 a t m}$ respectively. On the other hand, the surface layer is affected by a 272 short-term exchange with the overlaying atmosphere, therefore the saturation values in the 273 upper 25 m layer, and air-sea flux computation of both gases, were computed using monthly 274 mean measurements from the two meteorological stations nearest in latitude to the Strait of 275 Gibraltar, namely Mace Head (Ireland, $53.33^{\circ} \mathrm{N}$ ) and Izaña (Tenerife, Spain, $28.3^{\circ} \mathrm{N}$ ) 276 (http://ds.data.jma.go.jp/gmd/wdcgg/). Due to the marked latitudinal gradient of $\mathrm{CH}_{4}$, and to a 
277 lesser extent for $\mathrm{N}_{2} \mathrm{O}$ (Dlugokencky et al., 1994), atmospheric ratios from these two 278 meteorological stations were linearly interpolated versus latitude. For consistency,

279 measurements data from the NOAA/ESRL were used in both cases, $\mathrm{xN}_{2} \mathrm{O}_{\text {atm }}$ and $\mathrm{xCH}_{4 a t m}$, and 280 the values are summarized in Table 2.

281 The gas air-sea flux $(F)$ was calculated as:

$282 \quad F=k_{w}\left(C_{w}-C_{a}\right)$

283 where $k_{w}\left(\mathrm{~cm} \mathrm{~h}^{-1}\right)$ is the gas transfer coefficient as a function of wind speed at $10 \mathrm{~m}$ height $\left(\mathrm{U}_{10}\right.$

284 in $\mathrm{m} \mathrm{s}^{-1}$ ), $C_{w}$ is the measured $\mathrm{N}_{2} \mathrm{O}$ seawater concentration, and $C_{a}$ is the equilibrium $\mathrm{N}_{2} \mathrm{O}$ 285 concentration in seawater based on the molar atmospheric ratio explained above. $k_{w}$ was 286 calculated based on the combined linear and quadratic $k_{w}$-wind speed relationship proposed by

287 Nightingale et al. (2000): $k_{w}=0.222 U_{10}{ }^{2}+0.333 U_{10}{ }^{*}(S c / 600)^{-1 / 2}$

288 where $\mathrm{Sc}$ is the Schmidt number calculated for $\mathrm{N}_{2} \mathrm{O}$ and $\mathrm{CH}_{4}$ as a function of the temperature, 289 according to Wanninkhof et al. (1992). The wind speed data were provided by Puertos del 290 Estado, recorded at the buoy moored in the Gulf of Cadiz, and then corrected to $10 \mathrm{~m}$ height 291 using the formula by Large and Pond (1981). Daily averaged wind speed was used for the $k_{w}$ 292 calculation.

294 2.2.3. Water transport and $\mathrm{N}_{2} \mathrm{O}$ exchange through the Strait of Gibraltar

295 Computation of the flux of $\mathrm{N}_{2} \mathrm{O}$ through the Strait requires a proper identification of the two 296 layers that form the inverse-estuarine exchange of waters in the Strait. Previous studies have 297 reported that this bi-layer scheme results in a mean net transport $Q_{0}=Q_{A I W}+Q_{M O W}$, equal to $2980.038 \pm 0.007 \mathrm{~Sv}$ (Sverdrups, $1 \mathrm{~Sv}=10^{6} \mathrm{~m}^{3} \mathrm{~s}^{-1}$ ) [Soto-Navarro et al., 2010], which is equivalent to 299 a net evaporation of $0.6 \mathrm{~m} \mathrm{y}^{-1}$ in the Mediterranean, and where $\mathrm{Q}_{\mathrm{Alw}}$ and $\mathrm{Q}_{\mathrm{MOW}}$ stand for the 300 transport of Atlantic and Mediterranean waters respectively. In this work, the continuous 301 measurements of $\mathrm{Q}_{\text {MOW }}$ recorded at the Espartell Sill (Figure 1) and provided by Huertas et al. 302 (2012) have been used. Details regarding equipment, data recording and treatment are 303 explained in Sánchez-Román et al. (2009). From $\mathrm{Q}_{\text {MOW }}$ and taking into account the long-term 304 barotropic flow $\left(Q_{0}\right)$, computation of $Q_{\text {AIw }}$ is straightforward. Since the depth and thickness of 305 the interface between the two water masses are highly variable throughout the channel due to 306 topography and hydrodynamic processes occurring at different temporal scales, the interface 
307 that marks the separation of layers has been identified here according to the salinity criterion 308 given by Huertas et al. (2012). Briefly, at the westernmost part of the Strait (ES, St 1), a salinity 309 of 37.0 delimits the boundary between AIW and MOW and consequently, the portion of the 310 water column exhibiting lower salinity values than those chosen for AMI definition was 311 incorporated into the AIW, whereas the rest of the water column down to the sea floor was

312 included within the MOW. From this it was possible to calculate a mean $\mathrm{N}_{2} \mathrm{O}$ concentration in 313 each layer, which was required for the calculation of the net flux of this gas through the Strait 314 according to the equation:

$$
F_{N}=F_{\text {MOW }}-F_{\text {AIW }}=\left(\rho_{\text {MOW }} \times Q_{\text {MOW }} \times\left[N_{2} \mathrm{O}\right]_{\text {MOW }}\right)-\left(\rho_{\text {AIW }} \times Q_{\text {AIW }} \times\left[\mathrm{N}_{2} \mathrm{O}\right]_{\text {AIW }}\right)
$$
where $\rho, Q$ and $\left[\mathrm{N}_{2} \mathrm{O}\right]$ indicate water density, water transport and mean $\mathrm{N}_{2} \mathrm{O}$ concentration in

318 each layer; and so $\mathrm{F}_{\text {MOW }}$ and $\mathrm{F}_{\text {AIw }}$ denote the $\mathrm{N}_{2} \mathrm{O}$ fluxes into the Mediterranean and the Atlantic respectively. Densities for the MOW and AIW were 1029 and $1027 \mathrm{~kg} \mathrm{~m}^{-3}$, respectively.

\section{Results and discussion}

\subsection{East-West and vertical distribution of $\mathrm{N}_{2} \mathrm{O}$ and $\mathrm{CH}_{4}$}

324 Figure 2 shows the spatial distribution of $\mathrm{N}_{2} \mathrm{O}$ and $\mathrm{CH}_{4}$ in the Strait of Gibraltar together with the 325 thermohaline properties in the water column, $\mathrm{O}_{2}$ and nitrate, for the cruise performed in May 3262013 as a snapshot. The most remarkable feature for all the properties is the pronounced vertical gradient, which can be linked to the presence of the AMI delimited by isohaline 37 at the westernmost station. The interface can be traced by a sharply halocline (Fig. 2), extending from east to west throughout the whole channel. As previously described (e.g., Bray et al., 1995; Huertas et al., 2009), the location of the AMI becomes more shallow toward the east, moving from $150 \mathrm{~m}$ depth at the western station to $60 \mathrm{~m}$ at station 3 ; the $\mathrm{AMI}$ is therefore deeper, thicker, fresher and colder in the westernmost part of the Strait. The upper layer mainly corresponds to the SAW, with typical salinity around 36.4 and a surface temperature of $18{ }^{\circ} \mathrm{C}$

334 on the western side and $17^{\circ} \mathrm{C}$ on the eastern side for this particular time of the year (Fig. 2 and

335 Fig. 3). Below the AMI, the deeper layer filled by the MOW occupies a larger volume in the water column on the eastern side and its presence is characterized by temperatures ranging 
337 from 13.0 to $13.4{ }^{\circ} \mathrm{C}$ and salinity above 38.00 (Fig. 2). Dissolved $\mathrm{O}_{2}$ decreases with depth and 338 concentrations fluctuate from $243 \mu \mathrm{mol} \mathrm{kg}^{-1}$ on the surface (St1) (SAW) to a minimum of 162 $339 \mu \mathrm{mol} \mathrm{kg}{ }^{-1}$ at $250 \mathrm{~m}$ depth on the eastern side of the channel, coinciding with the presence of the 340 "Mediterranean tongue" (Fig. 2). The $\mathrm{O}_{2}$ distribution observed here follows the east-west and 341 vertical features already reported by other studies, with concentrations also being in line with 342 those measured in the past (Minas et al 1991; de la Paz et al 2008). Nitrate concentration 343 shows minimum values (undetectable levels $<0.06 \mu \mathrm{mol} \mathrm{kg}{ }^{-1}$ ) within the upper $50 \mathrm{~m}$ of the 344 water column in the westernmost part of the Strait, and increases to a maximum of $10.2 \mu \mathrm{mol}$ $345 \mathrm{~kg}^{-1}$ within the MOW (St3, $250 \mathrm{~m}$ depth) coinciding with the $\mathrm{O}_{2}$ minimum. East of the Camarinal 346 Sill, nitrate levels in the upper layer increase and reach $3.6 \mu \mathrm{mol} \mathrm{kg}{ }^{-1}$ (Fig. 2). This nutrient 347 enrichment may be attributable to mixing processes occurring from the interaction of the two 348 main flows at this particular section of the Strait, where the nutrient-enriched MOW injects 349 nitrate into the AIW (Macías et al., 2007a). The spatial distribution of nitrate and the levels 350 observed here are in agreement with those measured in the past (Minas et al., 1991; Dafner et 351 al., 2003; de la Paz et al., 2008; Macías et al., 2007a) and with more recent observations at the

352 GIFT time series station (Huertas et al., 2012).

353 The spatial pattern for $\mathrm{N}_{2} \mathrm{O}$ distribution follows closely those for $\mathrm{O}_{2}$ and nitrate (Fig. 2). Thus, $354 \mathrm{~N}_{2} \mathrm{O}$ concentration presents minimum values at the surface layer of the western entrance of the 355 Strait, increasing gradually towards the east; in May 2013, this increasing latitudinal gradient 356 varies from $7.79 \mathrm{nmol} \mathrm{kg}$ at St. 1 to $8.94 \mathrm{nmol} \mathrm{kg}^{-1}$ at St. 3. In addition, $\mathrm{N}_{2} \mathrm{O}$ increases with 357 depth, to $11.25 \mathrm{nmol} \mathrm{kg}^{-1}$ in the MOW, coinciding with the minimum in $\mathrm{O}_{2}$ concentration. Unlike 358 the rest of the properties analysed, $\mathrm{CH}_{4}$ did not show a clear vertical distribution associated with 359 the bi-layer circulation scheme (Fig. 2) although it still shows a trend in which higher 360 concentrations are present in the upper layer and diminish with depth to a minimum.

361 When the bulk of the data collected in all the campaigns is considered, a vertical gradient for 362 temperature, salinity, $\mathrm{N}_{2} \mathrm{O}$ and $\mathrm{CH}_{4}$ is also clearly noticeable (Fig. 3). Temporal variability of 363 these parameters can be seen particularly in the upper layer (see Fig. 3), where $\theta, \mathrm{N}_{2} \mathrm{O}$ and $\mathrm{CH}_{4}$ 364 concentrations show the most variability; this may be related to the temperature cycle on the 365 seasonal scale, as analyzed in detail in section 3.4. Regarding the water column at lower 366 depths, the high vertical variability observed between data obtained on different cruises and at 
depths between 50 and $300 \mathrm{~m}$ may be attributed both to the position of the AMI during sampling

368 and to tidally-induced hydrodynamic processes.

369 The general trends described for the cruise performed in May 2013 (Fig. 2) reflect the vertical 370 trends when the complete database is evaluated (Fig. 3): thus, in the upper $25 \mathrm{~m}$, salinity and

371 temperature values range from 35.8 to 36.6 and from 14.7 to $23.44{ }^{\circ} \mathrm{C}$ respectively, 372 corresponding to the thermohaline properties of the SAW. Then temperature progressively 373 decreases as salinity increases moving through the AMI; below the interface, temperature and 374 salinity show low spatio-temporal variability compared to the upper layer, with values varying 375 from 12.9 and $13.4{ }^{\circ} \mathrm{C}$ and from 38.0 to 38.5 respectively. $\mathrm{N}_{2} \mathrm{O}$ concentrations in the upper layer 376 oscillate from 6.55 to $8.83 \mathrm{nmol} \mathrm{kg}^{-1}$ and increase progressively with depth following the 377 distribution of the two main water masses (AIW and MOW); and below $300 \mathrm{~m}$ depth, where only $378 \mathrm{MOW}$ is found, $\mathrm{N}_{2} \mathrm{O}$ concentrations range from 9.68 to $11.25 \mathrm{nmol} \mathrm{kg}{ }^{-1} . \mathrm{CH}_{4}$ concentrations 379 show the opposite trend to $\mathrm{N}_{2} \mathrm{O}$ : data collected in February 2012 and May 2013 fall within a 380 similar range of concentrations in the upper layer (for salinity $<37.0 ; 1.56-2.78 \mathrm{nmol} \mathrm{kg}$ ) and 381 minimum $\mathrm{CH}_{4}$ concentrations were observed at depths below $300 \mathrm{~m}$ at Station 3, with values 382 ranging from 1.13 to $2.0 \mathrm{nmol} \mathrm{kg}{ }^{-1}$. On the other hand, $\mathrm{CH}_{4}$ measurements in November 2014 383 present maximum levels around $150 \mathrm{~m}$ extending from West to East, and unexpectedly reach 384 the highest values recorded, equivalent to $4.94 \mathrm{nmol} \mathrm{kg}{ }^{-1}$ at Station 1 , which subsequently 385 decrease eastwards (Fig. 3). This vertical pattern corresponds to an episodic event, since that 386 cruise was performed immediately following an intense storm that lasted nearly 3 weeks with 387 high winds of $20 \mathrm{~m} \mathrm{~s}^{-1}$, which may have pushed coastal waters with elevated levels of $\mathrm{CH}_{4}$ 388 (Ferrón et al., 2010a) towards the Strait or may have resuspended sediments that also 389 contributed to increased $\mathrm{CH}_{4}$ concentrations.

390

\section{3.2. $\mathrm{N}_{2} \mathrm{O}$ and $\mathrm{CH}_{4}$ distribution within water masses}

392 Identification of water masses present in the Strait can be also derived from the T-S plot shown 393 at the top of Figure 4; this plot brings together the complete set of data collected at the GIFT 394 station during the six cruises conducted. Fig. 4a reveals the presence of three main water 395 masses: the SAW, which is detected on the upper left side, with salinity nearly constant $(\sim 36.4)$ 396 and a temperature fluctuation of $\sim 6^{\circ} \mathrm{C}$ as a result of the seasonal variations. The salinity 
397 minimum detected in the lower left corner of Fig. 4a corresponds to the footprint of the NACW, 398 with a more frequent presence on the westernmost side of the Strait at a depth of around 100 $399 \mathrm{~m}$, in agreement with previous observations at the GIFT station (Huertas et al., 2009). The 400 MOW can be identified in the right lower corner of the T-S plot, with a very constant signature 401 during all the cruises along the longitudinal axis of the Strait. The AMI is also distinguishable in 402 the lower part, being characterized by a salinity gradient, since it is the result of mixing between 403 two water bodies, the AIW and the MOW. This description matches the classic T-S pattern described traditionally in the region (Gascard and Richez, 1985). Regarding the presence of each water mass, Bray et al. (1995), using temperature and salinity data of 313 vertical CTD profiles obtained at different times of the year, estimated that, on average, the composition of the upper layer is $50 \%$ SAW, $40 \% \mathrm{NACW}$ and $10 \% \mathrm{MOW}$, whereas in the lower layer, the composition is $90 \%$ MOW, $2 \%$ SAW and $8 \%$ NACW. More recent studies based on continuous recordings indicate that the presence of NACW in the lower layer is almost zero (Garcia-

410 Lafuente et al., 2007).

411 Biogeochemical differences between the NACW and the SAW can be identified from the AOUsalinity pattern (Fig. 4b). In particular, it is evident that AOU values of up to $60 \mu \mathrm{mol} \mathrm{kg}{ }^{-1}$ may be associated with salinities close to 36.0 ; these values decrease progressively with salinity, and

414 fall to almost 0 , even reaching negative values at salinities lower than 36.5 . These AOU signals 415 coincide with those observed in earlier studies conducted in the Strait and in the nearby Gulf of 416 Cadiz (Ait-Ameur et al., 2006; Flecha et al., 2012), which distinguished the presence of two 417 types of NACW: the warmer Eastern North Atlantic Central Water of subtropical origin, which is 418 oxygen-saturated, and the colder subpolar Eastern North Atlantic Central Water, located below 419 the former in depth, in which the AOU levels increase (Ríos et al., 1992; Pollard et al., 1996; 420 Pérez et al., 2001). Pérez et al. (2001) attributed the deeper AOU maximum to the 421 remineralization of organic matter near the coast of Africa linked to the northwest African 422 upwelling system.

423 In the various different water masses, the relationship between $\mathrm{N}_{2} \mathrm{O}$ and salinity (Fig. 4c) closely 424 resembles the $\mathrm{AOU}$ pattern The maximum $\mathrm{N}_{2} \mathrm{O}$ concentration in the Atlantic inflow of around $42510.6 \mathrm{nmol} \mathrm{kg}^{-1}$ (cruise July 2011 , St. 1 , depth $175 \mathrm{~m}$ ) was found at the salinity value of $\sim 36.0$ 426 that marks the presence of the NACW, with levels decreasing down to $6.5 \mathrm{nmol} \mathrm{kg}^{-1}$ at salinity 
36.5 (cruise July 2011 , St. 1 , depth 10 m), which is indicative of the SAW. As for AOU, the $\mathrm{N}_{2} \mathrm{O}$

428 distribution suggests that the $\mathrm{N}_{2} \mathrm{O}$ signature differs between the two branches of the AIW, with a

429 higher $\mathrm{N}_{2} \mathrm{O}$ content being present in the NACW compared with the SAW (Fig. 4.c). The highest

$430 \quad \mathrm{~N}_{2} \mathrm{O}$ concentrations observed in the Strait (between 9.68 and $11.25 \mathrm{nmol} \mathrm{kg}^{-1}$ ) are present in the

431 MOW, as they were measured at salinities > 38 (Fig. 4.c). Both NACW and MOW were

432 oversaturated in $\mathrm{N}_{2} \mathrm{O}$, with oversaturation values up to $120 \%$ and $124 \%$, respectively. AOU and

$433 \quad \mathrm{~N}_{2} \mathrm{O}$ show a similar relationship with salinity, with a nearly straight line of mixing between the

434 Atlantic water masses (SAW and NACW) and the MOW, suggesting that both variables are

435 acting as conservative parameters; this behavior is not surprising in the Strait of Gibraltar, as it

436 was previously described for $\mathrm{O}_{2}$ (Minas et al., 1991), because the time scales of mixing

437 processes are too short to allow changes through biological activity. In contrast, $\mathrm{CH}_{4}$ levels did

438 not show a clear relationship with salinity (Fig. 4.d), although higher $\mathrm{CH}_{4}$ concentrations (up to

$4394.94 \mathrm{nmol} \mathrm{kg}^{-1}$ in Nov 2014) were generally observed in the shallower SAW, and the lower

440 values could be associated with the MOW $\left(1.13 \mathrm{nmol} \mathrm{kg}{ }^{-1}\right)$. In the surface layer $\mathrm{CH}_{4}$ oscillates

441 between undersaturation in February 2012 (88\%) and oversaturation in November (133\%), with

442 the saturation level decreasing to $47 \%$ in the MOW.

443 No direct observations for $\mathrm{N}_{2} \mathrm{O}$ or $\mathrm{CH}_{4}$ in the Strait of Gibraltar have been found in the literature.

444 Ferrón et al. (2010a; b) described the spatiotemporal variability of the two gases in coastal

445 waters of the adjacent north-eastern shelf of the Gulf of Cadiz. That study reported a steep

446 gradient of both $\mathrm{N}_{2} \mathrm{O}$ and $\mathrm{CH}_{4}$ from the continent to the ocean, as the inner zone of the shelf is

447 strongly affected by river and continental inputs; its authors reported values for $\mathrm{CH}_{4}$ in May

4482007 that reached concentrations as high as $28.61 \mathrm{nM}$ in bottom waters, whereas a minimum of

$4491.64 \mathrm{nM}$ was measured in surface offshore waters, corresponding to saturation values of $108 \%$

450 and $100 \%$ respectively (Ferrón et al., 2010a). In the case of $\mathrm{N}_{2} \mathrm{O}$, levels varied from $8.2 \mathrm{nM}$ in

451 May 2007 to $28.5 \mathrm{nM}$ in November 2006, which correspond to saturation values of $100 \%$ to

$452335 \%$, respectively, for the region of the Gulf closer to the Strait of Gibraltar, with less influence

453 of continental inputs (Ferrón et al., 2010b). Our study shows concentrations of $\mathrm{N}_{2} \mathrm{O}$ in the Strait

454 that are more similar to those found by Walter et al. (2006) in oceanic waters of the cold-

455 temperate North Atlantic. In fact, these authors reported relatively uniform $\mathrm{N}_{2} \mathrm{O}$ concentrations

456 of around $8.5 \mathrm{nmol} \mathrm{kg}{ }^{-1}$ in the surface layer, and higher values $\left(\sim 11.3 \mathrm{nmol} \mathrm{kg}{ }^{-1}\right)$ below the 
thermocline and down to the bottom. Moreover, Forster et al. (2009) also gave ranges of $\mathrm{N}_{2} \mathrm{O}$ and $\mathrm{CH}_{4}$ in the North Atlantic that roughly match the values observed for both the NACW and SAW in the Strait of Gibraltar. The low $\mathrm{CH}_{4}$ values found in the MOW (Fig. $2 \mathrm{f}$ and $4 \mathrm{~d}$ ) are similar to the $\mathrm{CH}_{4}$ levels in deep waters reported in other studies, such as those of Keir et al. (2005) in the Northeast Atlantic and Yoshida et al. (2011) in the South Pacific.

462

\subsection{Biogeochemical processes and $\mathrm{N}_{2} \mathrm{O}$ and $\mathrm{CH}_{4}$ patterns in the Strait of Gibraltar}

The most relevant biogeochemical parameters analyzed in relation to $\mathrm{N}_{2} \mathrm{O}$ distribution are those assumed to be directly connected with the production pathways of this gas, such as oxygen, AOU and nitrate $\left(\mathrm{NO}_{3}{ }^{-}\right)$. In our study, positive relationships are found between $\Delta \mathrm{N}_{2} \mathrm{O}$ and $A O U$ (Fig. 5.a; $\mathrm{r}^{2}=0.73$ ) and between $\Delta \mathrm{N}_{2} \mathrm{O}$ and $\mathrm{NO}_{3}{ }^{-}$(Fig. 5.b; $\left.\mathrm{r}^{2}=0.62\right)$ for the complete database, which indicate that nitrification is indeed favored when oxygen concentration decays in the medium and would be consistent with the proposition that nitrification is the major production process in the North Atlantic (Yoshinari, 1976; Oudot et al., 2002; Nevison et al., 2003). Typically, the slope of the correlation between $\Delta \mathrm{N}_{2} \mathrm{O}$ and AOU provides a means to estimate the $\mathrm{N}_{2} \mathrm{O}$ yield per $\mathrm{O}_{2}$ molecule consumed during nitrification. Therefore, the slope of the regression line of $\Delta \mathrm{N}_{2} \mathrm{O}$ vs $\mathrm{AOU}$ gives a rough estimate of $\mathrm{N}_{2} \mathrm{O}$ production per mole of $\mathrm{O}_{2}$ consumed; in the Strait of Gibraltar this approach gives a result of $0.018 \mathrm{nmol} \mathrm{N}_{2} \mathrm{O} / \mu \mathrm{mol} \mathrm{O}_{2}$. However, in the particular case of the Strait of Gibraltar, where the water column is characterized by intense advection in the AIW and MOW layers, and by a marked vertical mixing, the slope of the correlation between $\Delta \mathrm{N}_{2} \mathrm{O}$ and $\mathrm{AOU}$ can also reflect phenomena superimposed over the nitrification process, particularly in the upper layer; this could therefore lead to a misinterpretation of the trend. As shown in Fig. 5, a different range of variability for $\Delta \mathrm{N}_{2} \mathrm{O}$ and AOU can be detected in the AIW compared to that in the MOW. In fact, taking into consideration the plots of $\mathrm{AOU}$ and $\mathrm{N}_{2} \mathrm{O}$ versus salinity (Fig. 4), which depict a conservative behavior during mixing in the AMI, it may be that the high degree of correlation between $\Delta \mathrm{N}_{2} \mathrm{O}$ and $\mathrm{AOU}$ is also the result of the conservative pattern of the two properties during mixing of the AIW and MOW at the interface layer. Nevison et al. (2003) evaluated the global distribution of the $\Delta \mathrm{N}_{2} \mathrm{O}-\mathrm{AOU}$ yield in the subsurface ocean and found that correlation slopes between $\Delta \mathrm{N}_{2} \mathrm{O}$ and $\mathrm{AOU}$ are not a reliable gauge of the 
biological $\mathrm{N}_{2} \mathrm{O}$ yield per mole of $\mathrm{O}_{2}$ consumed, because the slopes are strongly influenced by mixing gradients. They also concluded that the $\Delta \mathrm{N}_{2} \mathrm{O} / \mathrm{AOU}$ ratio calculated from individual data pairs, rather than from the $\Delta \mathrm{N}_{2} \mathrm{O}$ - AOU correlation, offers the best means of estimating the biological yield of $\mathrm{N}_{2} \mathrm{O}$ production per mole of $\mathrm{O}_{2}$ consumed. Therefore, the $\Delta \mathrm{N}_{2} \mathrm{O} / \mathrm{AOU}$ ratio from each pair of data has been computed in this study. As a result, the ratios in figure 5 show very scattered values for AOU levels, less than $40 \mu \mathrm{mol} \mathrm{kg}{ }^{-1}$, that are consistent with the SAW values and with the $\mathrm{N}_{2} \mathrm{O}$ values that are also near saturation (see Fig. 4), whereas for AOU

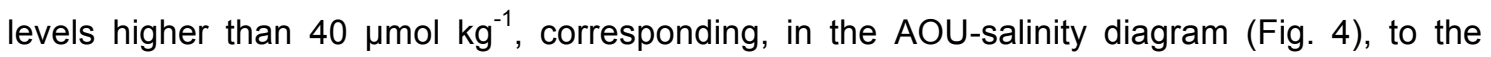
NACW and the MOW, the $\triangle \mathrm{N}_{2} \mathrm{O} / \mathrm{AOU}$ ratios range between 0.013 and $0.032 \mathrm{nmol} \mathrm{N}_{2} \mathrm{O} / \mu \mathrm{mol}$ $\mathrm{O}_{2}$. The average ratio calculated for the NACW (AOU> 40; salinity $\left.<36.5\right)$ is $0.029 \pm 0.005 \mathrm{nmol}$ $\mathrm{N}_{2} \mathrm{O} / \mu \mathrm{mol} \mathrm{O}_{2}$, and $0.020 \pm 0.003 \mathrm{nmol} \mathrm{N}_{2} \mathrm{O} / \mu \mathrm{mol} \mathrm{O}_{2}$ in the case of the MOW (AOU $>60$; salinity $>38) . \Delta N_{2} \mathrm{O} / \mathrm{AOU}$ ratios in the Strait are relatively low compared to other ocean regions although, despite the slight fluctuations observed, our estimations fall within the range of those previously found by Walter et al. (2006) in the North Atlantic, with slope values between 0.022 and 0.045 for cold temperate latitudes, which are also consistent with the values given by Nevison et al. (2003); the latter authors pointed out that the lowest values of the $\Delta N_{2} \mathrm{O} / \mathrm{AOU}$ ratio are found in the Atlantic Ocean and are equivalent to 0.02 at latitudes between 20 and 40 ${ }^{\circ} \mathrm{N}$. Unfortunately, there are no previous estimations of the $\Delta \mathrm{N}_{2} \mathrm{O} / \mathrm{AOU}$ ratio in the MOW passing through the Strait, or in the Mediterranean basin, that would enable a specific comparison to be made with the values obtained in our study. In fact, the $\mathrm{N}_{2} \mathrm{O}$ concentrations presented here are the first measurements made in the MOW, and so may serve as a starting point for tracking the evolution of this trace gas in the Mediterranean Sea by means of continuous monitoring of the MOW at the GIFT time series station. Recently, current values of nitrate and AOU have been reported on a basin scale in a wide study carried out by Tanhua et al. (2013). The distribution of

511 this parameter can be used as an approach to evaluate nitrification processes in the

512 Mediterranean, as these authors compiled biogeochemical data collected in 2011 during 3

513 oceanographic cruises covering an east-west section from the Gulf of Cadiz to the Levantine

514 Basin (Tanhua et al., 2013). According to these latter results, the Mediterranean Sea is well

515 oxygenated, and even the oxygen minimum layer (OML) found at intermediate depths is characterized by oxygen concentrations of the order of $180 \mu \mathrm{mol} \mathrm{kg}{ }^{-1}\left(\mathrm{AOU} \sim 70-80 \mu \mathrm{mol} \mathrm{kg}{ }^{-1}\right)$. 
517 This finding may be attributed to the active and rapid ventilation of the Mediterranean Sea 518 (Roether and Schlitzer, 1991; Stöven, 2011), and to the low rate of primary production present 519 in the surface waters of certain Mediterranean sub-basins (Pujo-Pay et al., 2011). The relatively 520 low $\mathrm{AOU}$ values found in the Mediterranean Sea support the low $\Delta \mathrm{N}_{2} \mathrm{O} / \mathrm{AOU}$ ratio observed in 521 the Strait in relation to those characterizing other ocean regions. Even though the $\Delta \mathrm{N}_{2} \mathrm{O} / \mathrm{AOU}$ 522 ratio is low, nitrate and AOU concentrations within the MOW (Fig. 4) coincide with the maximum 523 levels of both parameters found at deep and intermediate waters in the Western basin by 524 Tanhua et al. (2013). $\mathrm{N}_{2} \mathrm{O}$ production is particularly relevant in several "hot spot" regions, such 525 as the eastern tropical Pacific and the Arabian Sea, where $\mathrm{O}_{2}$ falls to very low levels and the $526 \Delta \mathrm{N}_{2} \mathrm{O} / \mathrm{AOU}$ ratio is one order of magnitude higher than that reported in this study (up to 0.27 $\mathrm{nmol} \mathrm{N}_{2} \mathrm{O} / \mu \mathrm{mol} \mathrm{O}_{2}$ ). Apart from these areas, there is a less intense but significant production

528 whose distribution varies with $\mathrm{O}_{2}$ and depth (Nevison et al., 2003).

529 Unlike $\mathrm{N}_{2} \mathrm{O}, \mathrm{CH}_{4}$ did not exhibit any significant correlation with $\mathrm{AOU}$, nitrate or any other 530 biogeochemical parameter in the Strait. Generally in the ocean, surface waters are oversaturated in $\mathrm{CH}_{4}$, and sometimes maxima also occur at the base of the thermocline,

532 associated with the chlorophyll maximum. This common feature is not discernible in the Strait of 533 Gibraltar, which is probably due to the reduced chlorophyll and primary production present in 534 this region due to the low residence time of the waters moving along the Strait (Minas et al., 535 1991; Macías et al., 2007a). The average $\mathrm{CH}_{4}$ saturation in the SAW and NACW 536 (salinities $<36.5 ; z>25 \mathrm{~m}$ depth) is $74 \pm 16 \%$, whereas the most striking feature is that the vertical 537 profile of $\mathrm{CH}_{4}$ depicts high undersaturation values within the MOW, with average 538 undersaturation equal to $66 \pm 16 \%$ (salinity $>38$ ). This finding can be attributed to the oxidative 539 consumption of methane during the transit time of this water mass passing through the 540 Mediterranean basin; clearly more data would be required to discern any vertical trend or 541 identify the processes underlying such variability. Furthermore, $\mathrm{CH}_{4}$ measurements in 542 November 2014 show maximum concentrations at a depth of around $150 \mathrm{~m}$ extending from 543 West to East and reach unexpectedly the highest values recorded (Fig. 3), equivalent to $270 \%$, 544 in the AIW layer, which subsequently decrease eastwards; but surprisingly, the $\mathrm{CH}_{4}$ saturation 545 values at the surface and in the deep layer show similar values in other cruises (Fig. 3). As 546 already mentioned, this vertical pattern corresponds to an episodic event, since that cruise was 
547 made immediately following an intense storm that lasted nearly 3 weeks. There are several 548 possible explanations for this $\mathrm{CH}_{4}$ source: advection from coastal water from the Gulf of Cadiz 549 with elevated levels of $\mathrm{CH}_{4}$ (Ferrón et al., 2010a) towards the Strait, remobilization of sediments 550 that also contributed to increased $\mathrm{CH}_{4}$ concentrations; and storm-induced methane release from

551 the mud volcanoes or diapiric structures hosting methane-hydrate that are abundant in the 552 continental margin of the Gulf of Cadiz (Somoza et al., 2002). Although some studies indicate 553 that $\mathrm{CH}_{4}$ originated in those mud volcanoes from the Gulf of Cadiz is completely consumed due 554 to the intense microbial consumption on the seafloor (Niemann et al., 2006), the impact of the 555 episodic storm could have induced the release of $\mathrm{CH}_{4}$, as previously reported in other 556 continental margins, such as in the Arctic continental shelf (Shakhova et al., 2007).

558 3.4. $\mathrm{N}_{2} \mathrm{O}$ and $\mathrm{CH}_{4}$ in the surface layer: seasonality of gas distribution and the air-sea 559 exchange

560 The surface water properties in the Strait of Gibraltar are those corresponding to the SAW, 561 which is the main contributor to the upper AIW, since the NACW appears normally at 562 intermediate depths at the westernmost part of the Strait (Stations 1 and 2; 100-150 m depth;

563 Fig. 2, Fig. 3). Further, the minimum surface seawater temperature (SST) recorded for our study 564 period was $15{ }^{\circ} \mathrm{C}$ in February 2012, whereas a maximum SST of $22{ }^{\circ} \mathrm{C}$ was recorded in July 565 2011. In order to evaluate the seasonal coverage of our dataset, the surface SST in the Strait of 566 Gibraltar was compared with the continuous temperature record for our study period (2011567 2014) obtained at a buoy moored in the Gulf of Cadiz that is part of the marine observational 568 network of Puertos del Estado. Fig. 6 shows the climatological mean of SST calculated from the 569 buoy data. The high correlation found between our discrete temperature measurements and the 570 continuous records confirms that our dataset covers appropriately the minimum, maximum and 571 inflection points of the sinusoidal shape of the seasonal variability, and hence, possesses a 572 good seasonal coverage and is representative of the annual temperature cycle. In comparison 573 to the seasonal variability of SST, salinity variations in the SAW were very small (see Fig.3) and 574 ranged from 35.95 to 36.5 .

575 In order to identify and evaluate the seasonal cycle of $\mathrm{N}_{2} \mathrm{O}$ and $\mathrm{CH}_{4}$ concentrations in surface 576 waters, averaged data for each cruise in the upper $12 \mathrm{~m}$ (the sampling depth closest to surface 
577 repeated most frequently during all cruises, see Fig.3) were considered. The $\mathrm{N}_{2} \mathrm{O}$ surface 578 concentration showed the maximum values $\left(8.74 \pm 0.13 \mathrm{nmol} \mathrm{kg}^{-1}\right)$ in February (Fig. 6), 579 coinciding with the minimum annual temperature, whereas the lowest $\mathrm{N}_{2} \mathrm{O}$ surface 580 concentration was measured in July $(7.19 \pm 1.06)$, when the maximum temperature for our study 581 period was recorded. The surface layer was nearly in equilibrium with the atmosphere, with 582 saturation values of $100 \%$, during the cruises carried out in winter and spring, and slightly 583 oversaturated during summer (Table 2). These results suggest that temperature is the main 584 factor responsible for the seasonal variability of $\mathrm{N}_{2} \mathrm{O}$ in the surface layer. The amplitude of the 585 annual range of salinity recorded in the Strait ( 0.5 salinity units) had only a minor impact on the 586 solubility variations at the surface (1\%). The annual influence of temperature on gas 587 concentration (Table 2) can be evaluated from the ratio between the seasonal amplitude of the

$588 \mathrm{~N}_{2} \mathrm{O}$ observed $\left(=1.6 \mathrm{nmol} \mathrm{kg}{ }^{-1}\right)$ and the seasonal amplitude of $\mathrm{N}_{2} \mathrm{O}$ saturation concentration $589\left(=1.8 \mathrm{nmol} \mathrm{kg}^{-1}\right)$. Accordingly, temperature variations would explain $87 \%$ of the seasonal 590 variability of $\mathrm{N}_{2} \mathrm{O}$ at the surface layer, suggesting that $\mathrm{N}_{2} \mathrm{O}$ surface concentration is driven 591 mainly by solubility. Freing et al. (2009) demonstrated that both $\mathrm{N}_{2} \mathrm{O}$ surface concentration and 592 air-sea $\mathrm{N}_{2} \mathrm{O}$ fluxes in the North Atlantic follow a seasonal cycle similar to that of $\mathrm{CO}_{2}$. This 593 seasonal cycle can be described by a harmonic function and is controlled primarily by 594 temperature, allowing the computation of a reasonably accurate mean flux. In this area, de la 595 Paz et al. (2011) demonstrated, by reconstructing the $\mathrm{CO}_{2}$ seasonal cycle with data collected 596 during 36 cruises, that solubility is also the main mechanism governing $\mathrm{CO}_{2}$ concentration in 597 surface waters. In contrast to the trend found in the Strait of Gibraltar, a positive correlation 598 between temperature and $\mathrm{N}_{2} \mathrm{O}$ oversaturation was also found in the nearby coastal waters of 599 the Gulf of Cadiz, which was attributed to the enhancement of nitrification during the summer 600 time due to the increasing bacterial activity with temperature, as this area is considerably 601 affected by organic matter inputs from estuaries and aquaculture activities (Ferrón et al., 602 2010b).

603 Regarding the contribution of other factors, such as biological processes, to gas distribution in 604 surface waters of the Strait, it is worth pointing out that in situ observations and modelling 605 studies have reported a very fast transit time of particles due to the strong advection, especially 606 in the upper layer, and hence significant phytoplankton growth cannot be sustained (Macias et 
607 al., 2007a). The upper layer in the central channel of the Strait that flows rapidly towards the

608 Mediterranean is normally considered oligotrophic. In theory, primary productivity usually leads

609 to the generation of organic matter, which, being subsequently recycled, may be a potential

610 source of $\mathrm{N}_{2} \mathrm{O}$. This is not clearly the case in the Strait, as surface oligotrophy, together with the

611 high oxygen availability, would result in a low or insignificant nitrification activity.

612 In order to examine short-term variability of $\mathrm{N}_{2} \mathrm{O}$ and other possible sources of variability in the

613 upper layer, we evaluated the deviations of the measured $\mathrm{N}_{2} \mathrm{O}$ concentrations with respect to

614 the average cruise values for $\mathrm{N}_{2} \mathrm{O}$, hereinafter named the " $\mathrm{N}_{2} \mathrm{O}$ anomaly". Similarly, the SST

615 anomaly has been computed as the difference between each value of SST measured

616 individually and the averaged SST of the cruises. Figure 7 shows the high negative correlation

617 found between the SST anomaly and the $\mathrm{N}_{2} \mathrm{O}$ anomaly $\left(r^{2}=0.81\right)$. Positive anomalies

618 correspond to St. 1, whereas negative anomalies are mainly observed in St. 3. However, those

619 anomalies show no seasonal pattern or correlation with SST or salinity. This is consistent with

620 the hypothesis that $\mathrm{N}_{2} \mathrm{O}$-enriched colder water could be brought to the surface via vertical

621 mixing. The distribution pattern of SST, nitrate and other parameters in surface water exhibit a

622 marked east-west variability, which can be attributed to the presence of internal waves, as has

623 previously been described for dissolved inorganic carbon (de la Paz et al., 2008) and for $\mathrm{CO}_{2}$

624 (de la Paz et al., 2011). These internal waves generated at the Camarinal sill lift the interface

625 and trigger the upwelling of $\mathrm{N}_{2} \mathrm{O}$-enriched deeper waters that then enter the upper surface layer.

626 In addition, the bathymetry of the channel causes the AMI to uplift towards the east, being

627 shallower at St. 3, where the MOW occupies a larger volume of the water column. The detection

628 of water-ascending events triggered by internal waves based solely on salinity changes is,

629 however, difficult. Other sources of variability in $\mathrm{N}_{2} \mathrm{O}$ content have been explored, such as wind

630 speed, but no correlation was found. Contrary to the waters proximal to the Strait, where a clear

631 relationship between zonal winds and upwelling episodes has been identified, both in the Gulf of

632 Cadiz (Navarro et al., 2006) and in the Alboran Sea (Macías et al., 2007b), these wind-induced

633 upwellings are not expected to be relevant in the channel, due mainly to the one-dimensional

634 character of the flow in the Strait of Gibraltar, which is characterized by very high current

635 velocities.

636 
637 As for $\mathrm{CH}_{4}$, Figure 6 depicts the minimum concentration in the surface waters observed in 638 February $2011\left(2.16 \pm 0.14 \mathrm{nmol} \mathrm{kg}^{-1}\right)$ and the maximum level in November $2014(2.79 \pm 0.22$ $639 \mathrm{nmol} \mathrm{kg}{ }^{-1}$ ). Accordingly, saturation at the surface layer varied between 93\% in February 2012 640 and $126 \%$ in November 2014. Oversaturation in November and May is in agreement with typical 641 saturation values of $\mathrm{CH}_{4}$ in oceanic waters, which are of the order of $120 \%$ (Reeburgh, 2007). 642 However, there is no obvious explanation for the slight undersaturation reported in February 643 since no correlation was found between $\mathrm{CH}_{4}$ and SST or salinity and thus further 644 measurements are required for a more comprehensive analysis. It is noteworthy that similar $645 \mathrm{CH}_{4}$ undersaturation values $(\sim 95 \%)$ were also reported for February in 2007 in the offshore 646 waters of the Gulf of Cadiz by Ferrón et al.(2010a). On the other hand, there was no evidence

647 for in situ production during May or November that could account for the oversaturation values, 648 since no consistent correlation was observed between $\mathrm{CH}_{4}$ concentrations and biogeochemical 649 parameters such as chlorophyll or nutrients data that are available in the GIFT database. 650 Unfortunately, there are insufficient data on $\mathrm{CH}_{4}$ in surface water to allow the proper 651 identification of the seasonal cycle. The saturation anomaly $\left(\Delta \mathrm{CH}_{4}\right)$ has been signaled as the 652 major factor of uncertainty in the determination of the $\mathrm{CH}_{4}$ air-sea fluxes in oceanic waters 653 (Rhee et al., 2009) due to limitations in the instrumental determination of $\Delta \mathrm{CH}_{4}$, which, 654 particularly in this study, ranges from $-0.17 \pm 0.15 \mathrm{nmol} \mathrm{kg}^{-1}$ in February to $0.6 \pm 0.18 \mathrm{nmol} \mathrm{kg}^{-1}$ in 655 November. As in the case of $\mathrm{N}_{2} \mathrm{O}$, in order to evaluate the short-term variability, $\mathrm{CH}_{4}$ anomalies, 656 calculated as the difference between cruise-averaged $\mathrm{CH}_{4}$ concentration and each individual $657 \mathrm{CH}_{4}$ observation, were examined in relation to SST anomalies, but no significant correlation with 658 SST was observed.

660 Applying equation 2, and using the $\mathrm{N}_{2} \mathrm{O}$ and $\mathrm{CH}_{4}$ concentrations in water given in Table 2, airsea fluxes of $\mathrm{N}_{2} \mathrm{O}$ and $\mathrm{CH}_{4}$ were calculated (Table 2). Since $\mathrm{k}_{\mathrm{w}}$ formulation is a non-linear 662 function of wind speed, the air-sea exchange was computed first from the individual data pairs and subsequently averaged for each cruise. The resulting $\mathrm{N}_{2} \mathrm{O}$ air-sea flux $\left(\mathrm{F}_{\mathrm{N} 2 \mathrm{O}}\right)$ value

664 oscillated between $1.17 \pm 0.09 \mu \mathrm{mol} \mathrm{m}^{-2} \mathrm{~d}^{-1}$ in August 2011 and $0.02 \pm 0.06$ in November 2011 . 665 However, the $\mathrm{N}_{2} \mathrm{O}$ anomalies observed during each cruise (Table 2 and Fig. 2) due to vertical 666 mixing are higher than the seasonal variability of $\Delta \mathrm{N}_{2} \mathrm{O}$ and $\mathrm{F}_{\mathrm{N} 2 \mathrm{O}}$ (Table 2), and increase 
667 markedly towards the east. The magnitude of the $\mathrm{N}_{2} \mathrm{O}$ fluxes depends strongly on the $\Delta \mathrm{N}_{2} \mathrm{O}$,

668 and, although higher surface $\mathrm{N}_{2} \mathrm{O}$ concentrations were observed in winter, both the maximum

669 supersaturation and $\mathrm{F}_{\mathrm{N} 2 \mathrm{O}}$ occurred during the summer month. Nevertheless, it must be stated

670 that the net annual air-sea exchange of $\mathrm{N}_{2} \mathrm{O}$ was calculated from the cruise-averaged flux data

671 grouped into seasons (Fig. 6). On an annual basis, the net $\mathrm{N}_{2} \mathrm{O}$ flux in the Strait of Gibraltar is

$6720.35 \pm 0.27 \mu \mathrm{mol} \mathrm{m} \mathrm{d}^{-1}$ resulting in a near neutral transfer with the atmosphere. This behavior is

673 consistent with that of most of the ocean surface in the North Atlantic, which shows a negligible

$674 \mathrm{~N}_{2} \mathrm{O}$ net flux with the atmosphere (Nevison et al., 2003; Walter et al., 2006; Forster et al., 2009).

675 These low $\mathrm{N}_{2} \mathrm{O}$ flux values contrast with the high air-water $\mathrm{N}_{2} \mathrm{O}$ exchange values calculated in

676 the north-eastern shelf of the Gulf of Cadiz, which varied between $2.8 \pm 2.9 \mu \mathrm{mol} \mathrm{m} \mathrm{d}^{-1}$ and

$67715.3 \pm 9.3 \mu \mathrm{mol} \mathrm{m}{ }^{-2} \mathrm{~d}^{-1}$ in winter and summer, respectively (Ferrón et al., 2010b). As mentioned

678 above, the intense gradient of terrestrial inputs of $\mathrm{N}_{2} \mathrm{O}$ precursors in the continental shelf, as

679 well as the high microbial activity present normally in coastal areas in relation to the open

680 ocean, may be the main factors underlying the differences observed between the two

681 neighboring areas.

682 With regard to $\mathrm{CH}_{4}$, the Strait of Gibraltar behaves as a sink in February $\left(-0.15 \pm 0.12 \mu \mathrm{mol} \mathrm{m}{ }^{2} \mathrm{~d}^{1}\right)$

683 and as a source in May $\left(0.70 \pm 0.08 \mu \mathrm{mol} \mathrm{m}^{-2} \mathrm{~d}^{-1}\right)$ and November $\left(1.68 \pm 0.50 \mu \mathrm{mol} \mathrm{m}^{-2} \mathrm{~d}^{-1}\right)($ Table

684 2). The sink/source status of the Strait is consistent with the observations by Ferrón et al.

685 (2010a) in the north-eastern shelf waters of the Gulf of Cadiz for February and May

686 respectively, although those authors report $\mathrm{CH}_{4}$ flux values one order of magnitude higher than

687 those shown here. In that case, the levels of $\mathrm{CH}_{4}$ saturation were directly influenced by

688 continental inputs and benthic fluxes, and changed seasonally depending on the water

689 temperature (positively correlated) and the magnitude of the freshwater discharge (Ferrón et al.,

690 2010a).

691

692

\section{5. $\mathrm{N}_{2} \mathrm{O}$ balance in the Strait of Gibraltar}

693

694 To assess the main mechanism influencing inputs and outputs of $\mathrm{N}_{2} \mathrm{O}$ in the Strait of Gibraltar,

$695 \mathrm{~N}_{2} \mathrm{O}$ fluxes associated with the two main water flows has been compared to the air-sea

696 exchange of $\mathrm{N}_{2} \mathrm{O}$ at the surface of the waters in the region. The $\mathrm{N}_{2} \mathrm{O}$ exchange between the

697 Atlantic and the Mediterranean has been computed according to equation 4, thereby requiring 

in Fig. 2, $\left[\mathrm{N}_{2} \mathrm{O}\right]$ distribution is characterized by an increasing vertical gradient everywhere in the channel, reflecting the confluence of water masses with distinctive $\mathrm{N}_{2} \mathrm{O}$ signatures. Overall, the averaged $\left[\mathrm{N}_{2} \mathrm{O}\right]$ in the AIW penetrating into the Strait is $9.00 \pm 1.18 \mathrm{nmol} \mathrm{kg}^{-1}(\mathrm{n}=18$ in water with $\mathrm{S}<37$ at St. 1). Higher levels of $\left[\mathrm{N}_{2} \mathrm{O}\right]$ were detected in the MOW, with a more uniform vertical distribution than in the upper AIW layer and an average concentration of $10.26 \pm 0.27 \mathrm{nmol} \mathrm{kg}^{-1}$ $(n=17$ in waters with $S>37$ at St. 1). When net fluxes are calculated a net export from the Mediterranean to the Atlantic is obtained, which amounts to $682 \pm 20 \mathrm{mmol} \mathrm{s}^{-1}$. Considering a total surface area of the Strait of Gibraltar of $1500 \mathrm{~km}^{2}$, the net export of $\mathrm{N}_{2} \mathrm{O}$ per unit of area is $39 \mu \mathrm{mol} \mathrm{m} \mathrm{d}^{-2}$ towards the Atlantic. This flux can be now compared with the calculated annual mean air-sea $\mathrm{N}_{2} \mathrm{O}$ flux of the total $\mathrm{N}_{2} \mathrm{O}$ emission by the Strait of Gibraltar equal to $0.35 \mu \mathrm{mol} \mathrm{m}{ }^{-2}$ $\mathrm{d}^{-1}$. Therefore, the export of $\mathrm{N}_{2} \mathrm{O}$ from the Mediterranean towards the North Atlantic through the Strait of Gibraltar is more than one hundred times higher than the net emission of $\mathrm{N}_{2} \mathrm{O}$ to the atmosphere. Given to the complexity of the water circulation in the Strait of Gibraltar, especially due to the high tidal variability that complicates the observational strategy for measuring both

713 the water transport and the biogeochemical distribution pattern, one of the most debated issues

714 for estimating the exchange of water and substances through the Strait is the section where the 715 exchange is evaluated. For this study, water exchange and $\mathrm{N}_{2} \mathrm{O}$ concentrations were assessed 716 at Station 1, located at the Espartell Sill, where the $\mathrm{N}_{2} \mathrm{O}$ enrichment observed in the upper layer 717 due to the tidal-induced vertical mixing, do not affect our computations. Previous studies 718 (García-Lafuente et al., 2007, Sanchez-Roman et al., 2009), have taken the Espartel sill as the 719 reference spot for monitoring water exchange through the Strait, since at this particular section, 720 tidal currents in the MOW layer are not strong enough to reverse the subinertial flow and 721 consequently the fraction of MOW that returns to the Mediterranean basin can be considered 722 negligible.

723 Although the results of this study reveal an increase of $\mathrm{N}_{2} \mathrm{O}$ content at the surface layer in the 724 eastern entrance of the Strait, which may be associated with the tidal-induced mixing 725 processes, this short time-scale variability does not mask the seasonal variability and hence, $726 \mathrm{~N}_{2} \mathrm{O}$ concentration at the surface remains close to the equilibrium with the atmosphere, 727 reflecting the annual seasonal cycle. It can then be concluded that advection associated with 
the Atlantic and Mediterranean flows in the Strait of Gibraltar is the main mechanism governing the $\mathrm{N}_{2} \mathrm{O}$ distribution in the region, being two orders of magnitude larger than the air-sea

730 transport of $\mathrm{N}_{2} \mathrm{O}$.

731 According to the observed distribution pattern of $\mathrm{CH}_{4}$ in the water column, which does not

732 reflect a distribution in two layers unlike that observed for $\mathrm{N}_{2} \mathrm{O}$, and also due to the low gradient

733 of $\mathrm{CH}_{4}$ concentrations detected between the AIW and the MOW, more observations are needed

734 to make a reliable evaluation of the $\mathrm{CH}_{4}$ exchanged between Atlantic and Mediterranean 735 waters.

736

737

\section{Conclusions}

738

739

The vertical distribution of $\mathrm{N}_{2} \mathrm{O}$ concentrations in the Strait of Gibraltar presents typical features linked to the bi-layer circulation scheme proposed for this region, where the strong lateral advection and water mixing at the interface between the Atlantic and Mediterranean waters masses with different $\mathrm{N}_{2} \mathrm{O}$ signatures govern its spatial distribution. The SAW is characterized by $\mathrm{N}_{2} \mathrm{O}$ values in near-equilibrium with the atmosphere, with seasonal variability closely associated with the annual temperature cycle. In contrast, the deeper MOW, and to a lesser extent the NACW, show concentrations of $\mathrm{N}_{2} \mathrm{O}$ markedly far from the saturation concentrations. Data suggest that production by nitrification is the process underlying the $\mathrm{N}_{2} \mathrm{O}$ supersaturation observed in the NACW and the MOW. The vertical distribution of $\mathrm{CH}_{4}$ exhibits a high temporal variability in the upper Atlantic layer, with values near saturation concentrations in February and oversaturation during May and November. On the other hand, the notable undersaturation of

$750 \mathrm{CH}_{4}$ in the MOW may reflect intense $\mathrm{CH}_{4}$ oxidation activity at deep and intermediate levels in 751 the Mediterranean basin. Annually, the Strait of Gibraltar behaves as a very limited source for 752 atmospheric $\mathrm{N}_{2} \mathrm{O}$, with $\mathrm{CH}_{4}$ also being emitted in spring and fall but absorbed in winter. 753 However, the main contributor to the $\mathrm{N}_{2} \mathrm{O}$ balance in the region is horizontal transport, as the $754 \mathrm{~N}_{2} \mathrm{O}$ exchange between basins found is much greater than that produced by air-sea transference. The $\mathrm{N}_{2} \mathrm{O}$ and $\mathrm{CH}_{4}$ observations provided in this study represent valuable

756 information from a region of considerable geographic and oceanographic relevance - the only marine connection between the Atlantic and Mediterranean basins. 


\section{Acknowledgments.}

762 The excellent co-operation of the captains and the crews of R/V García del Cid, Cornide de 763 Saavedra, Hesperides and Socib are gratefully acknowledged. We also thank María Ferrer-

764 Marco and Manuel Arjonilla for collection and measurement of the samples. The authors are 765 also grateful to the Spanish "Puertos del Estado" for providing the meteorological data. 766 Comments by two anonymous reviewers significantly improved this paper. Funding for this work 767 was provided by the INGOS (Grant agreement 284274), CARBOCHANGE IP (264879GOCE) 768 and PERSEUS of the European Commission, the CATARINA Project supported by the MICINN 769 and co-funded by FEDER (CTM2010-17141/MAR)) and OSIMON project funded by the 770 Regional Government of Galicia (Xunta de Galicia, 09MDS035402PR).

771

772

773

References

774

775 Aït-Ameur, N., Goyet, C., 2006. Distribution and transport of natural and anthropogenic CO2 in the 776 Gulf of Cádiz. Deep Sea Res. Part II Top. Stud. Oceanogr. 53, 11-13, 1329-1343. doi: $777 \quad$ 10.1016/j.dsr2.2006.04.003

778 Álvarez, M., Pérez, F.F., Shoosmith, D.R., Bryden, H.L., 2005. Unaccounted role of Mediterranean 779 Water in the drawdown of anthropogenic carbon. J. Geophys. Res. 110, C9, C09S03.

780 Armi, L., Farmer, D., 1985. The internal hydraulics of the Strait of Gibraltar and associated sill and 781 narrows. Oceanologica Acta 8 (1), 37-46.

782 Bakker, D.C.E., Bange, H.W., Gruber, N., Johannessen, T., Upstill-Goddard, R.C., Borges, A.V., 783 Delille, B., Löscher, C.R., Naqvi, S.W.A., Omar, A.M., Santana-Casiano, J.M., 2014. Air784 Sea Interactions of Natural Long-Lived Greenhouse Gases (CO2, N2O, CH4) in a 785 Changing Climate, in: Liss, P.S., Johnson, M.T. (Eds.), Ocean-Atmosphere Interactions of 786 Gases and Particles, Springer Earth System Sciences. Springer Berlin Heidelberg, pp. 787 113-169.

788 Bange, H. W., Bell, T. G., Cornejo, M., Freing, A., Uher, G., Upstill-Goddard, R. C., and Zhang, G.: 789 MEMENTO: a proposal to develop a database of marine nitrous oxide and methane 790 measurements, Environ. Chem., 6, 195-197, doi:10.1071/en09033, 2009

791 Bange, H.W., Bergmann, K., Hansen, H.P., Kock, A., Koppe, R., Malien, F., Ostrau, C., 2010. 792 Dissolved methane during hypoxic events at the Boknis Eck time series station 793 (Eckernförde Bay, SW Baltic Sea). Biogeosciences 7, 4, 1279-1284. doi: 10.5194/bg-7$794 \quad 1279-2010$

795 Bethoux, J.P., Boukhary, M.S.E., Ruiz-Pino, D., Morin, P., Copin-Montégut, C., 2005. Nutrient, 796 Oxygen and Carbon Ratios, CO2 Sequestration and Anthropogenic Forcing in the 797 Mediterranean Sea, in: Saliot, A. (Ed.), The Mediterranean Sea, Handbook of 798 Environmental Chemistry. Springer Berlin Heidelberg, pp. 67-86. 
799 Boetius, A., Ravenschlag, K., Schubert, C.J., Rickert, D., Widdel, F., Gieseke, A., Amann, R., 800 Jørgensen, B.B., Witte, U., Pfannkuche, O. 2000. A marine microbial consortium 801 apparently mediating anaerobic oxidation of methane. Nature 407, 6804, 623-626. doi: $802 \quad 10.1038 / 35036572$

803 Boyce, F.M., 1975. Internal waves in t(Carini et al., 2014)he Strait of Gibraltar. Deep Sea Res. 22, 804 597-610.

805 Bray, N.A., Ochoa, J., Kinder, T.H., 1995. The role of the interface in exchange through the Strait 806 of Gibraltar. J. Geophys. Res. Oceans 100, C6, 10755-10776. doi: 10.1029/95JC00381

807 Bruno, M., Juan Alonso, J., Cózar, A., Vidal, J., Ruiz-Cañavate, A., Echevarría, F., Ruiz, J., 2002. 808 The boiling-water phenomena at Camarinal Sill, the strait of Gibraltar. Deep Sea Res. Part 809 II Top. Stud. Oceanogr., Canary Islands, Azores, Gibraltar Observations (Canigo) Volume 810 II: Studies of the Azores and Gibraltar regions 49, 19, 4097-4113. doi: 10.1016/S0967$811 \quad$ 0645(02)00144-3.

812 Carini, P., White, A.E., Campbell, E.O., Giovannoni, S.J., 2014. Methane production by phosphate813 starved SAR11 chemoheterotrophic marine bacteria. Nat Commun 5.

814 Ciais, P., C. Sabine, G. Bala, L. Bopp, V. Brovkin, J. Canadell, A. Chhabra, R. DeFries, J. 815 Galloway, M. Heimann, C. Jones, C. Le Quéré, R.B. Myneni, S. Piao and P. Thornton, 816 2013: Carbon and Other Biogeochemical Cycles. In: Climate Change 2013: The Physical 817 Science Basis. Contribution of Working Group I to the Fifth Assessment Report of the 818 Intergovernmental Panel on Climate Change [Stocker, T.F., D. Qin, G.-K. Plattner, M. 819 Tignor, S.K. Allen, J. Boschung, A. Nauels, Y. Xia, V. Bex and P.M. Midgley (eds.)]. $820 \quad$ Cambridge University Press, Cambridge, United Kingdom and New York, NY, USA.

821 Codispoti, L.A., 2010. Interesting Times for Marine N2O. Science 327, 5971, 1339-1340. doi: $822 \quad 10.1126 /$ science. 1184945

823 Codispoti, L.A., Yoshinari, T., Devol, A.H., 2005. Suboxic respiration in the oceanic water column. $824 \quad$ Oxford University Press, pp. 225-247.

825 Crutzen P J. The influence of nitrogen oxides on the atmospheric ozone content. Quarterly Journal 826 Review of the Meteorological Society. 1970; 96:320-325.

827 Crutzen, P.J., 1991. Methane's sinks and sources. Nature 350 (6317), 380-381

828 Dachs, J., Bayona, J.M., Raoux, C., Albaigés, J., 1997. Spatial, Vertical Distribution and Budget of 829 Polycyclic Aromatic Hydrocarbons in the Western Mediterranean Seawater. Environ. Sci. $830 \quad$ Technol. 31, 3, 682-688. doi: 10.1021/es960233j

831 Dafner, E., González-Dávila, M., Magdalena Santana-Casiano, J., Sempéré, R., 2001. Total 832 organic and inorganic carbon exchange through the Strait of Gibraltar in September 1997. 833 Deep Sea Res. Part Oceanogr. Res. Pap. 48, 5, 1217-1235. doi: 10.1016/S0967834 0637(00)00064-9

835 Dafner, E.V., Boscolo, R., Bryden, H.L., 2003. The N:Si:P molar ratio in the Strait of Gibraltar. 836 Geophys. Res. Lett. 30, 10, n/a-n/a. doi: 10.1029/2002GL016274 
837 de la Paz, M., Debelius, B., Macías, D., Vázquez, A., Gómez-Parra, A., Forja, J.M., 2008. Tidal838 induced inorganic carbon dynamics in the Strait of Gibraltar. Cont. Shelf Res. 28, 14, 839 1827-1837. doi: 10.1016/j.csr.2008.04.012

840 de la Paz, M., Huertas, E.M., Padín, X.-A., Gónzalez-Dávila, M., Santana-Casiano, M., Forja, J.M., 841 Orbi, A., Pérez, F.F., Ríos, A.F., 2011. Reconstruction of the seasonal cycle of air-sea

$842 \mathrm{CO} 2$ fluxes in the Strait of Gibraltar. Mar. Chem. 126, 1-4, 155-162. doi: 843 10.1016/j.marchem.2011.05.004

844 De Angelis MA, Lee C ,1994. Methane production during zooplankton grazing on marine $845 \quad$ phytoplankton. Limnol Oceanogr 39:1298-1308

846 Dlugokencky, E.J., Steele, L.P., Lang, P.M. and Masarie, K.A. 1994. The growth rate and 847 distribution of atmospheric methane. Journal of Geophysical Research 99: 17,021-17,043.

848 Dore, J.E., Popp, B.N., Karl, D.M., Sansone, F.J., 1998. A large source of atmospheric nitrous 849 oxide from subtropical North Pacific surface waters. Nature 396, 6706, 63-66. doi: $850 \quad 10.1038 / 23921$

851 Echevarría, F., García Lafuente, J., Bruno, M., Gorsky, G., Goutx, M., González, N., García, C.M., 852 Gómez, F., Vargas, J.M., Picheral, M., Striby, L., Varela, M., Alonso, J.J., Reul, A., Cózar, 853 A., Prieto, L., Sarhan, T., Plaza, F., Jiménez-Gómez, F., 2002. Physical-biological coupling 854 in the Strait of Gibraltar. Deep Sea Res. Part II Top. Stud. Oceanogr. 49, 19, 4115-4130. 855 doi: 10.1016/S0967-0645(02)00145-5.

856 Elbaz-Poulichet, F., C. Guieu, and N. H. Morley (2001), A reassessment of trace metal budgets in 857 the western Mediterranean Sea, Mar. Pollut. Bull., 42(8), 623-627, doi:10.1016/S0025858 326X(01)00065-0.

859 Ferrón, S., Ortega, T., Forja, J.M., 2010a. Temporal and spatial variability of methane in the north860 eastern shelf of the Gulf of Cádiz (SW Iberian Peninsula). J. Sea Res. 64, 3, 213-223. doi: $861 \quad$ 10.1016/j.seares.2010.02.007

862 Ferrón, S., Ortega, T., Forja, J.M., 2010b. Nitrous oxide distribution in the north-eastern shelf of the 863 Gulf of Cádiz (SW Iberian Peninsula). Mar. Chem. 119, 1-4, 22-32. doi: 864 10.1016/j.marchem.2009.12.003

865 Flecha, S., Pérez, F.F., Navarro, G., Ruiz, J., Olivé, I., Rodríguez-Gálvez, S., Costas, E., Huertas, 866 I.E., 2012. Anthropogenic carbon inventory in the Gulf of Cádiz. J. Mar. Syst. 92, 1, 67-75. 867 doi: 10.1016/j.jmarsys.2011.10.010

868 Forster, G., Upstill-Goddard, R.C., Gist, N., Robinson, C., Uher, G., Woodward, E.M.S., 2009. 869 Nitrous oxide and methane in the Atlantic Ocean between $50^{\circ} \mathrm{N}$ and $52^{\circ} \mathrm{S}$ : Latitudinal 870 distribution and sea-to-air flux. Deep Sea Res. Part II Top. Stud. Oceanogr. 56, 15, 964871976 . doi: $10.1016 /$ j.dsr2.2008.12.002

872 Freing, A., Wallace, D.W.R., Tanhua, T., Walter, S., Bange, H.W., 2009. North Atlantic production 873 of nitrous oxide in the context of changing atmospheric levels. Glob. Biogeochem. Cycles 87423,4, n/a-n/a. doi: 10.1029/2009GB003472.

875 Freing A, Wallace DWR, Bange HW (2012) Global oceanic production of nitrous oxide (N2O). $876 \quad$ Philos Trans R Soc B 367:1245-1255 
877 García Lafuente, J., Álvarez Fanjul, E., Vargas, J.M., Ratsimandresy, A.W., 2002. Subinertial 878 variability in the flow through the Strait of Gibraltar. J. Geophys. Res. Oceans 107, C10, 879 32-1-31-9. doi: 10.1029/2001JC001104

880 García Lafuente, J., Sánchez Román, A., Díaz del Río, G., Sannino, G., Sánchez Garrido, J.C., 881 2007. Recent observations of seasonal variability of the Mediterranean outflow in the Strait 882 of Gibraltar. J. Geophys. Res. Oceans 112, C10, n/a-n/a. doi: 10.1029/2006JC003992

883 Garçon, V.C., Bell, T.G., Wallace, D., Arnold, S.R., Baker, A., Bakker, D.C.E., Bange, H.W., Bates, 884 N.R., Bopp, L., Boutin, J., Boyd, P.W., Bracher, A., Burrows, J.P., Carpenter, L.J., Leeuw, 885 G. de, Fennel, K., Font, J., Friedrich, T., Garbe, C.S., Gruber, N., Jaeglé, L., Lana, A., Lee, 886 J.D., Liss, P.S., Miller, L.A., Olgun, N., Olsen, A., Pfeil, B., Quack, B., Read, K.A., Reul, N., 887 Rödenbeck, C., Rohekar, S.S., Saiz-Lopez, A., Saltzman, E.S., Schneising, O., Schuster, 888 U., Seferian, R., Steinhoff, T., Traon, P.-Y.L., Ziska, F., 2014. Perspectives and Integration 889 in SOLAS Science, in: Liss, P.S., Johnson, M.T. (Eds.), Ocean-Atmosphere Interactions of $890 \quad$ Gases and Particles, Springer Earth System Sciences. Springer Berlin Heidelberg, pp. $891 \quad 247-306$.

892 Gascard, J.-C., Richez, Z., 1985. Water masses and circulation in the western Alboran Sea, and in 893 the Straits of Gibraltar. Prog. Oceanogr. 15, 216.

894 Goreau, T.J., Kaplan, W.A., Wofsy, S.C., McElroy, M.B., Valois, F.W., Watson, S.W., 1980. 895 Production of NO2- and N2O by Nitrifying Bacteria at Reduced Concentrations of Oxygen. 896 Appl. Environ. Microbiol. 40, 3, 526-532.

897 Grasshoff, K., Ehrhardt, M., Kremling, K., 1983. Methods of Seawater Analysis, 2nd ed. Verlag 898 Chemie, Weinheim, Germany.

899 Huertas, I.E., Ríos, A.F., García-Lafuente, J., Makaoui, A., Rodríguez-Gálvez, S., Sánchez900 Román, A., Orbi, A., Ruíz, J., Pérez, F.F., 2009. Anthropogenic and natural CO2 exchange 901 through the Strait of Gibraltar. Biogeosciences 6, 647-662.

902 Huertas, I.E., Ríos, A.F., García-Lafuente, J., Navarro, G., Makaoui, A., Sánchez-Román, A., 903 Rodriguez-Galvez, S., Orbi, A., Ruíz, J., Pérez, F.F., 2012. Atlantic forcing of the 904 Mediterranean oligotrophy. Glob. Biogeochem. Cycles 26, 2, n/a-n/a. doi: $905 \quad 10.1029 / 2011 \mathrm{~GB} 004167$

906 Karl, D., \& Tilbrook, B. (1994). Production and transport of methane in oceanic particulate organic 907 matter Nature, 368 (6473), 732-734 DOI: 10.1038/368732a0

908 Karl DM, Beversdorf L, Björkman KM, Church MJ, Martinez A, Delong EF (2008) Aerobic 909 production of methane in the sea. Nat Geosci 1:473-478.

910 Keir, R.S., Greinert, J., Rhein, M., Petrick, G., Sültenfuß, J., Fürhaupter, K., 2005. Methane and 911 methane carbon isotope ratios in the Northeast Atlantic including the Mid-Atlantic Ridge $912 \quad\left(50^{\circ} \mathrm{N}\right)$. Deep Sea Res. Part Oceanogr. Res. Pap. 52, 6, 1043-1070. doi: $913 \quad$ 10.1016/j.dsr.2004.12.006

914 Large, W.G., Pond, S., 1981. Open ocean-momentum flux measurements in moderate to strong 915 winds. J. Phys. Oceanogr. 11, 324-336. 
916 Macías, D., Lubián, L.M., Echevarría, F., Huertas, I.E., García, C.M., 2008. Chlorophyll maxima 917 and water mass interfaces: Tidally induced dynamics in the Strait of Gibraltar. Deep Sea 918 Res. Part Oceanogr. Res. Pap. 55, 7, 832-846. doi: 10.1016/j.dsr.2008.03.008

919 Macías, D., Martin, A.P., García-Lafuente, J., García, C.M., Yool, A., Bruno, M., Vázquez-Escobar, 920 A., Izquierdo, A., Sein, D.V., Echevarría, F., 2007a. Analysis of mixing and biogeochemical 921 effects induced by tides on the Atlantic-Mediterranean flow in the Strait of Gibraltar through 922 a physical-biological coupled model. Prog. Oceanogr. 74, 2-3, 252-272. doi: $923 \quad$ 10.1016/j.pocean.2007.04.006

924 Macías, D., Navarro, G., Echevarría, F., García, C.M., Cueto, J.L., 2007b. Phytoplankton pigment 925 distribution in the northwestern Alboran Sea and meteorological forcing: A remote sensing 926 study. J. Mar. Res. 65, 4, 523-543. doi: 10.1357/002224007782689085

927 Minas, H.J., Coste, B., Le Corre, P., Minas, M., Raimbault, P., 1991. Biological and geochemical 928 signatures associated with the water circulation through the Strait of Gibraltar and in the 929 western Alboran Sea. J. Geophys. Res. Oceans 96, C5, 8755-8771. doi: $930 \quad 10.1029 / 91 J C 00360$

931 Naqvi, S.W.A., Bange, H.W., Farías, L., Monteiro, P.M.S., Scranton, M.I., Zhang, J., 2010. Marine 932 hypoxia/anoxia as a source of $\mathrm{CH} 4$ and $\mathrm{N} 2 \mathrm{O}$. Biogeosciences 7, 7, 2159-2190. doi: $933 \quad 10.5194 /$ bg-7-2159-2010

934 Naranjo, C., Garcia-Lafuente, J., Sannino, G., Sanchez-Garrido, J., 2014. How much do tides 935 affect the circulation of the Mediterranean Sea? From local processes in the Strait of 936 Gibraltar to basin-scale effects. Prog. Oceanogr. doi: 10.1016/j.pocean.2014.06.005

937 Navarro, G., Ruiz, J., 2006. Spatial and temporal variability of phytoplankton in the Gulf of Cádiz 938 through remote sensing images. Deep-Sea Research Part II: Topical Studies in 939 Oceanography 53, 11-13, 1241-1260. doi: 10.1016/j.dsr2.2006.04.014

940 Neill, C., Johnson, K.M., Lewis, E., Wallace, D.W., 1997. Accurate headspace analysis of $\mathrm{fCO}_{2}$ in 941 discrete water samples using batch equilibration. Limnol. Oceanogr. 42, 1774-1783.

942 Nevison, C. D., Weiss, R. F. and Erickson, D. J. 1995. Global oceanic emissions of nitrous oxide. 943 J. Geophys. Res. Oceans 100(C8), 15 809- 820.

944 Nevison, C., Butler, J.H., Elkins, J.W., 2003. Global distribution of N2O and the $\Delta$ N2O-AOU yield in 945 the subsurface ocean. Glob. Biogeochem. Cycles 17 (4) 1119,doi:10.1029/2003GB002068 946 Niemann, H., Duarte, J., Hensen, C., Omoregie, E.,Magalhães, V.H., Elvert, M., Pinheiro, L.M., 947 Kopf, A., Boetius, A., 2006. Microbial methane turnover at mud volcanoes of the Gulf of 948 Cadiz. Geochim. Cosmochim. Acta 70, 5336-5355

949 Nightingale, P.D., Liss, P.S., Schlosser, P., 2000. Measurements of air-sea gas transfer during an 950 open ocean algal bloom. Geophys. Res. Lett. 27, 14, 2117-2120. doi: $951 \quad$ 10.1029/2000GL011541

952 Oudot, C., Jean-Baptiste, P., Fourré, E., Mormiche, C., Guevel, M., Ternon, J.F., Le Corre, P., 953 2002. Transatlantic equatorial distribution of nitrous oxide and methane. Deep Sea Res. 954 Part Oceanogr. Res. Pap. 49, 7, 1175-1193. 
955 Peliz, A., Marchesiello, P., Santos, A.M.P., Dubert, J., Teles-Machado, A., Marta-Almeida, M., Le 956 Cann, B., 2009. Surface circulation in the Gulf of Cadiz: 2. Inflow-outflow coupling and the 957 Gulf of Cadiz slope current. J. Geophys. Res. Oceans 114, C3, n/a-n/a. doi: $958 \quad 10.1029 / 2008 J C 004771$

959 Pérez, F., Mintrop, L., Llinás, O., González-Dávila, M., Castro, C.G., Álvarez, M., Körtzinger, A., 960 Santana-Casiano, M., Rueda, M.J., Ríos, A.F., 2001. Mixing analysis of nutrients, oxygen 961 and inorganic carbon in the Canary Islands region. J. Mar. Syst. 28, 183-201. doi: 962 10.1016/S0924-7963(01)00003-3

963 Periañez, R., 2008. A Modelling Study on 137cs and 239,240pu Behaviour in the Albora?N Sea, 964 Western Mediterranean. En: Journal of environmental radioactivity. 2008. Vol. 99. Núm. 4. 965 Pag. 694-715

966 Pollard, R.T., Grifftths, M.J., Cunningham, S.A., Read, J.F., Pérez, F.F., Ríos, A.F., 1996. Vivaldi 9671991 - A study of the formation, circulation and ventilation of Eastern North Atlantic Central 968 Water. Prog. Oceanogr. 37, 167-192. doi: 10.1016/S0079-6611(96)00008-0

969 Pujo-Pay, M., Conan, P., Oriol, L., Cornet-Barthaux, V., Falco, C., Ghiglione, J.-F., Goyet, C., 970 Moutin, T., Prieur, L., 2011. Integrated survey of elemental stoichiometry (C, N, P) from the 971 western to eastern Mediterranean Sea. Biogeosciences 8, 4, 883-899. doi: 10.5194/bg-8$972 \quad 883-2011$

973 Reeburgh WS (2007) Oceanic methane biogeochemistry. Chem. Rev 107(2):486-513

974 Rhee TS, Kettle AJ, Andreae MO (2009) Methane and nitrous oxide emissions from the ocean: a 975 reassessment using basin-wide observations in the Atlantic. J Geophys Res 114,D12304. 976 doi:10.1029/2008JD011662

977 Ríos, A.F., Perez, F.F., Fraga, F., 1992. Water masses in the upper and middle North Atlantic 978 Ocean east of the Azores. Deep Sea Res. Part Oceanogr. Res. Pap. 39, 645-658. doi: 979 10.1016/0198-0149(92)90093-9

980 Roether, W., Schlitzer, R., 1991. Eastern Mediterranean deep water renewal on the basis of 981 chlorofluoromethane and tritium data. Dyn. Atmospheres Oceans, The Mediterranean Sea 982 15, 3-5, 333-354. doi: 10.1016/0377-0265(91)90025-B

983 Sánchez-Román,A., G.Sannino, J.Garcla-Lafuente, A. Carillo, and F. Criado-Aldeanueva 2009, 984 Transport estimates at the western section of the Strait of Gibraltar: A combined 985 experimental and numerical modelling study,J. Geophys. Res., 114, C06002, doi: $986 \quad 10.1029 / 2008 J C 005023$

987 Schmidt S., 2006. Impact of the Mediterranean Outflow Water on particle dynamics in intermediate 988 waters of the North-East Atlantic, as revealed by 234 Th and 228 Th. Marine Chemistry $989 \quad 100: 289-298$

990 Schroeder, K., García-Lafuente, J., Josey, S.A., Artale, V., Buongiorno Nardelli, B., Carrillo, A., 991 Gacic, M., Gasparini, G.P., Herrmann, M., Lionello, P., Ludwig, W., Millot, C., Özsoy, E., 992 Pisacane, G., Sánchez-Garrido, J.C., Sannino, G., Santoleri, R., Somot, S., Struglia, M.,

993 Stanev, E., Taupier-Letage, I., Tsimplis, M.N., Vargas-Yáñez, M., Zervakis, V., Zodiatis, G., 2012.

994 Circulation of the Mediterranean Sea and its variability, in: The Climate of the 

pp. 187-238.

997 Scranton, M. I. and P. G. Brewer 1977. Occurrence of methane in the near-surface waters of the 998 western subtropical North Atlantic. Deep-Sea Research, v. 24, 127-138.

999 Shakhova, N., Semiletov, I., Leifer, I., Sergienko, V., Salyuk, A., Kosmach, D.,

1000 Chernykh, D., Stubbs, C., Nicolsky, D., Tumskoy, V., Gustafsson, Ö., 2014. Ebullition and storm1001 induced methane release from the East Siberian Arctic Shelf. Nat. Geosci. 7, 1, 64-70. doi: $1002 \quad 10.1038 /$ ngeo2007

1003 Somoza, L., Diaz-Del-Rio, V., Vaszquez, J.T., Pinheiro, L.M., Hernandez-Molina, F.J., 2002. 1004 Numerous methane gas-related sea floor structures identified in Gulf of Cadiz. EOS 83, $1005 \quad 541-547$.

1006 Soto-Navarro, J., F. Criado-Aldeanueva, J. García-Lafuente, and A. Sánchez-Román (2010), 1007 Estimation of the Atlantic inflow through the Strait of Gibraltar from climatological and in 1008 situ data, J. Geophys. Res., 115, C10023, doi:10.1029/2010JC006302

1009 Stöven, T., Tanhua, T., 2014. Ventilation of the Mediterranean Sea constrained by multiple 1010 transient tracer measurements. Ocean Sci 10, 3, 439-457. doi: 10.5194/os-10-439-2014

1011 Tanhua, T., Hainbucher, D., Schröder, K., Cardin, V., Álvarez, M., Civitarese, G., 2013. The 1012 Mediterranean Sea system: a review and an introduction to the special issue. Ocean Sci 1013 Discuss 10, 2, 581-617. doi: 10.5194/osd-10-581-2013

1014 Upstill-Goddard, R.C., Rees, A.P., Owens, N.J.P., 1996. Simultaneous high-precision 1015 measurements of methane and nitrous oxide in water and seawater by single phase 1016 equilibration gas chromatography. Deep Sea Res. Part Oceanogr. Res. Pap. 43, 10, 16691017 1682. doi: $10.1016 /$ S0967-0637(96)00074-X

1018 Unesco, 1986. Progress on oceanographic tables and standards 1983-1986. Work and 1019 recomendations of UNESCO/SCOR/ICES/IAPSO Joint panel. UNESCO Technical Papers 1020 in Marine Science 50.

1021 Van Geen, A. and E.A. Boyle (1990) Variability of trace metal fluxes through the Straits of Gibraltar, 1022 Paleoclimatol. Paleogeog. Paleoecol. 89: 65-80.

1023 Walter, S., Bange, H.W., Breitenbach, U., Wallace, D.W.R., 2006. Nitrous oxide in the North $1024 \quad$ Atlantic Ocean. Biogeosciences 3, 4, 607-619.

1025 Wanninkhof, R., 1992. Relationship between wind speed and gas exchange. J Geophys Res 97 , $1026 \quad 25,7373-7382$.

1027 Weiss, R.F., Price, B.A., 1980. Nitrous oxide solubility in water and seawater. Mar. Chem. 8, 4, 1028 347-359. doi: 10.1016/0304-4203(80)90024-9

1029 Wiesenburg, D.A., Guinasso Jr, N.L., 1979. Equilibrium solubilities of methane, carbon monoxide, 1030 and hydrogen in water and sea water. J. Chem. Eng. Data 24, 4, 356-360.

1031 Yoshida O, Inoue HY, Watanabe S, Suzuki K, Noriki S (2011) Dissolved methane distribution in the 1032 South Pacific and the Southern Ocean in austral summer. J Geophys Res 116,C07008. doi:10.1029/2009JC006089 
1034 Yoshinari, T., 1976. Nitrous oxide in the sea. Mar. Chem. 4, 2, 189-202. doi: 10.1016/03044203(76)90007-4

1036

1037

\section{LIST OF FIGURES}

1039

1040 Figure 1. Map of the study area including the bathymetry and locations of the GIFT stations.

1042 Figure 2. Vertical distribution of potential temperature, salinity, dissolved oxygen, nitrate, nitrous 1043 oxide $\left(\mathrm{N}_{2} \mathrm{O}\right)$ and methane $\left(\mathrm{CH}_{4}\right)$ along the Strait of Gibraltar with data corresponding to the 1044 cruise carried out in May 2013. The contour black line shows the salinity 37 isocline, to track the 1045 depth of the AMI.

1046

1047 Figure 3. Vertical distribution of potential temperature ( $\theta$ ), salinity, $\mathrm{N}_{2} \mathrm{O}$ and $\mathrm{CH}_{4}$ concentrations 1048 for Stations1, 2 and 3 for all the cruises carried out for the GITF series from 2001 to 2014. The 1049 red filled symbols correspond to the cruise in May 2013.

1050

1051 Figure 4. Scatter diagram plot of: a) potential temperature versus salinity ( $\theta$ ); b) AOU versus 1052 salinity; c) $\mathrm{N}_{2} \mathrm{O}$ concentrations (filled symbols) and saturation $\mathrm{N}_{2} \mathrm{O}$ concentrations versus salinity (open symbols); and c) $\mathrm{CH}_{4}$ concentrations (filled symbols) and saturation $\mathrm{CH}_{4}$ concentrations 1054 versus salinity (open symbols). Acronyms corresponding to the water masses present in the Strait (NACW, SAW and MOW) have also been included. The thermohaline properties of the

1056 AMI have been included in plot a).

1057

1058 Figure 5. a) $\mathrm{N}_{2} \mathrm{O}$ excess $\left(\Delta \mathrm{N}_{2} \mathrm{O}\right)$ in relation to $\mathrm{AOU}$; and (b) nitrate $\mathrm{NO}_{3}{ }^{-1}$ for the complete GIFT 1059 database. Open symbols correspond to AIW and filled symbols to MOW; c) Ratio of $\Delta \mathrm{N}_{2} \mathrm{O} / \mathrm{AOU}$ 1060 versus $\mathrm{AOU}$ for observations at depths more than $25 \mathrm{~m}$. The equations for the linear

1061 regressions are: in a) $\Delta \mathrm{N}_{2} \mathrm{O}=0.28+0.018 \mathrm{AOU}, \mathrm{r}^{2}=0.73$; and in b) $\Delta \mathrm{N}_{2} \mathrm{O}=0.18+0.14 \mathrm{NO}_{3^{-}}$; $1062 \quad r^{2}=0.62$.

1064 Figure 6. Annual cycle at the surface layer in the Strait of Gibraltar for: a) surface seawater 1065 temperature (SST), $\mathrm{N}_{2} \mathrm{O}, \mathrm{N}_{2} \mathrm{O}$ saturation and $\mathrm{N}_{2} \mathrm{O}$ air-sea fluxes; and (b) SST, $\mathrm{CH}_{4}, \mathrm{CH}_{4}$ 
1066 saturation and $\mathrm{CH}_{4}$ air-sea fluxes. For $\mathrm{N}_{2} \mathrm{O}$ and $\mathrm{CH}_{4}$ concentrations in surface waters, averaged

1067 data for each cruise in the upper $12 \mathrm{~m}$ were considered. The surface SST corresponds to the

1068 continuous temperature record for our study period (2011-2014) obtained from a buoy moored

1069 in the Gulf of Cadiz, which is part of the marine observational network of Puertos del Estado.

1070 This figure shows the climatological mean of SST calculated for that period.

1071

1072 Figure 7. Anomalies of $\mathrm{N}_{2} \mathrm{O}$ versus anomalies of the sea surface temperature (SST). Anomalies

1073 were calculated as the difference between each $\mathrm{N}_{2} \mathrm{O}$ and SST measurement at the surface and

1074 the average obtained for each cruise for surface values. The correlation line for all the data in

1075 plot is: $\mathrm{N}_{2} \mathrm{O}$ anomaly $=-3.95-0.34 \cdot \mathrm{SST} ; \mathrm{r}^{2}=0.81$

1076

1077

\section{TABLES}

1079

1080 Table 1. Acronyms, dates and vessels used for the campaigns referred to in this study

1081

1082

\begin{tabular}{lll}
\hline Campaign & Date & Ship \\
\hline GIFT 0611 & 26 July 2011 & RV García del Cid \\
GIFT 0811 & 4-5 August 2011 & RV Cornide de Saavedra \\
GIFT 1111 & 10 November 2011 & RV García del Cid \\
GIFT 0212 & 27-28 February 2012 & RV García del Cid \\
GIFT 0513-Ficaram XV & 23 May 2013 & RV Hespérides \\
GIFT 1114 & 3 November 2014 & RV SOCIB \\
\hline
\end{tabular}

1083

1084

1085

1086

1087

1088

1089

1090

1091

1092

1093 
1094 Table 2. Cruise-averaged surface values (upper $12 \mathrm{~m}$ ) for temperature, $\mathrm{N}_{2} \mathrm{O}$ and $\mathrm{CH}_{4}$ 1095 concentrations in water, and their respective saturation values (\%), molar fraction in 1096 atmosphere, wind speed and air sea fluxes of $\mathrm{N}_{2} \mathrm{O}$ and $\mathrm{CH}_{4}$. The values for the atmospheric 1097 mixing ratio $\left(\mathrm{xN}_{2} \mathrm{O}\right.$ and $\left.\mathrm{xCH}_{4}\right)$ are calculated using monthly mean measurements from the two 1098 meteorological stations nearest in latitude to the Strait of Gibraltar, namely Mace Head (Ireland, $109953.33^{\circ} \mathrm{N}$ ) and Izaña (Tenerife, Spain, $\left.28.3^{\circ} \mathrm{N}\right)$ (http://ds.data.jma.go.jp/gmd/wdcgg/). The 1100 atmospheric ratios from these two meteorological stations were linearly interpolated versus 1101 latitude. The atmospheric ratios from both meteorological stations were linearly interpolated 1102 versus latitude.

1103

\begin{tabular}{|c|c|c|c|c|c|c|c|c|c|c|}
\hline $\begin{array}{l}\text { F } \\
\text { D. } \\
\text { D }\end{array}$ & 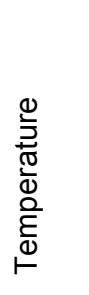 & 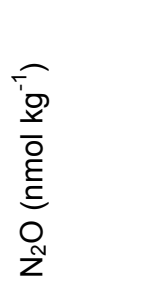 & 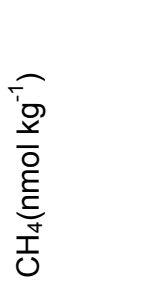 & 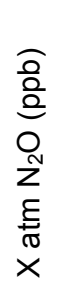 & 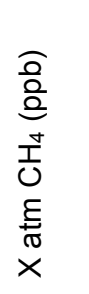 & 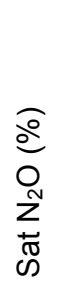 & 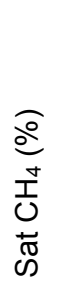 & 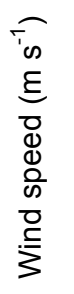 & 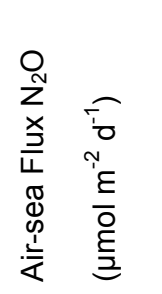 & 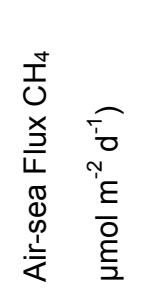 \\
\hline Jul 2011 & 22.04 & $7.19 \pm 1.06$ & -- & 324 & 1827 & 104 & -- & 2.2 & $0.12 \pm 0.27$ & -- \\
\hline Aug 2011 & 20.20 & $7.91 \pm 0.66$ & -- & 324 & 1828 & 108 & -- & 5.4 & $1.17 \pm 0.09$ & -- \\
\hline Nov 2011 & 18.96 & $7.59 \pm 0.30$ & -- & 325 & 1855 & 100 & -- & 4.9 & $0.02 \pm 0.06$ & -- \\
\hline Feb 2012 & 15.02 & $8.74 \pm 0.13$ & $2.16 \pm 0.14$ & 325 & 1859 & 101 & 93 & 3.7 & $0.11 \pm 0.09$ & $-0.15 \pm 0.12$ \\
\hline May 2013 & 17.75 & $8.00 \pm 0.30$ & $2.66 \pm 0.17$ & 326 & 1864 & 101 & 117 & 5.4 & $0.13 \pm 0.40$ & $0.70 \pm 0.08$ \\
\hline Nov 2014 & 17.76 & $8.25 \pm 0.37$ & $2.79 \pm 0.22$ & 326 & 1872 & 104 & 126 & 7 & $0.99 \pm 0.55$ & $1.68 \pm 0.50$ \\
\hline
\end{tabular}

1104

1105

1106

1107

1108

1109

1110

1111

1112

1113

1114

1115

1116

1117

1118 


\section{FIGURES}

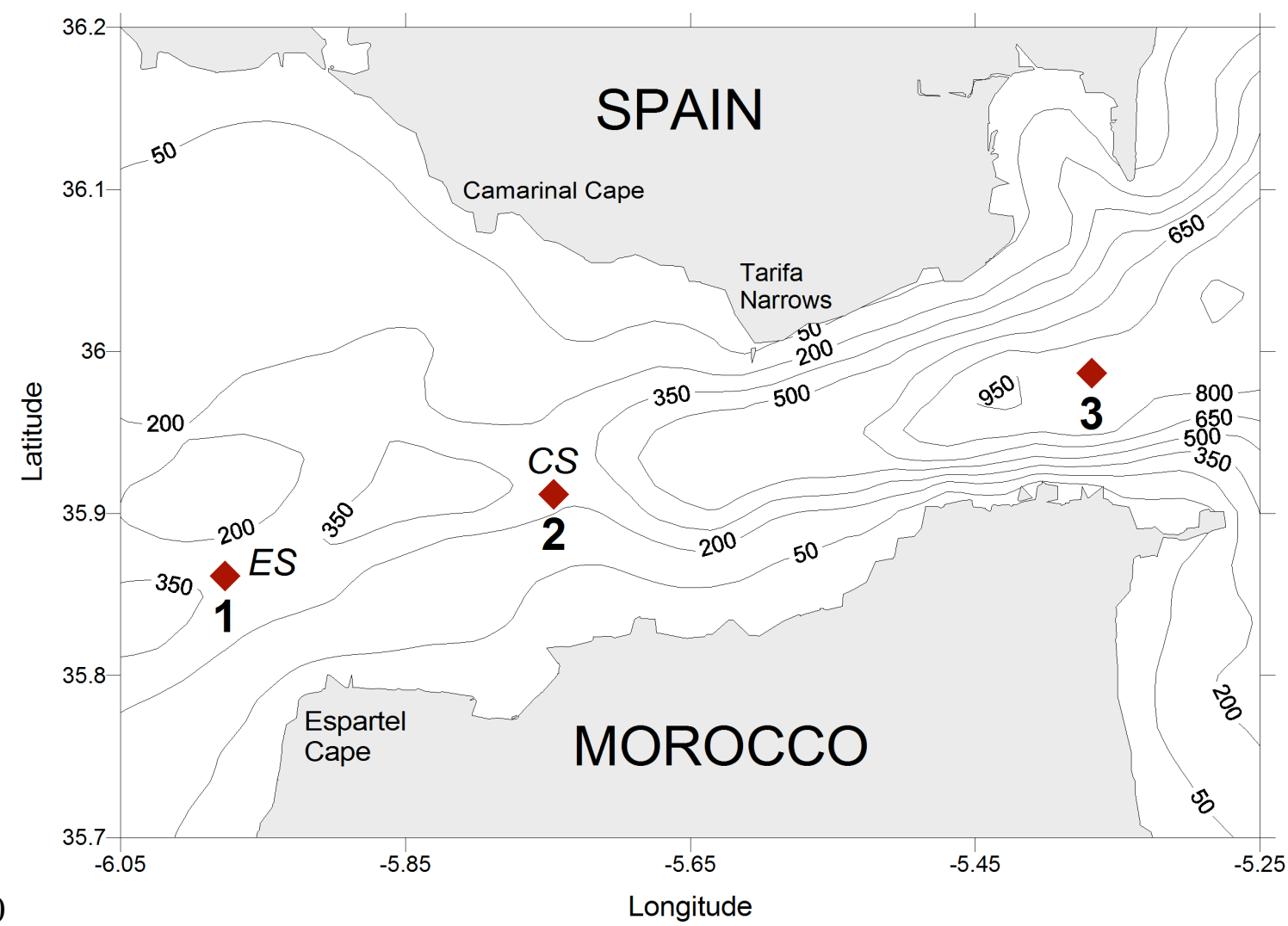

1121

1122
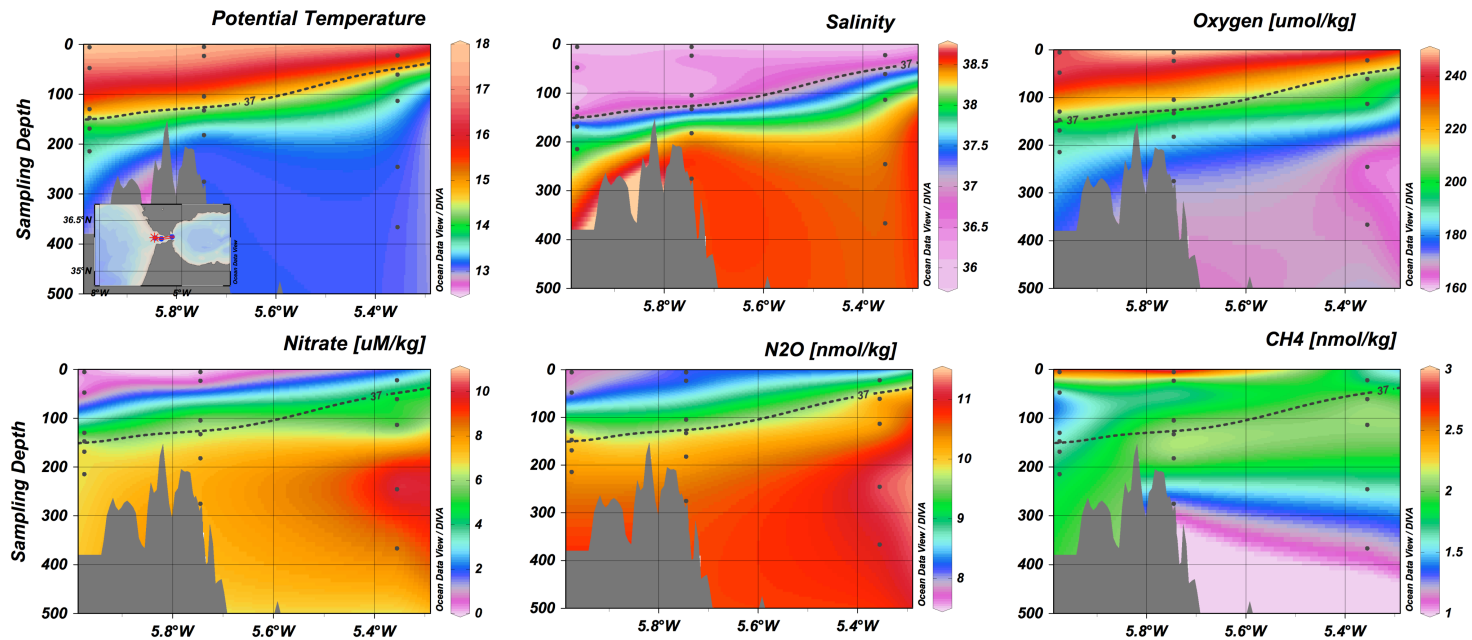

1124 


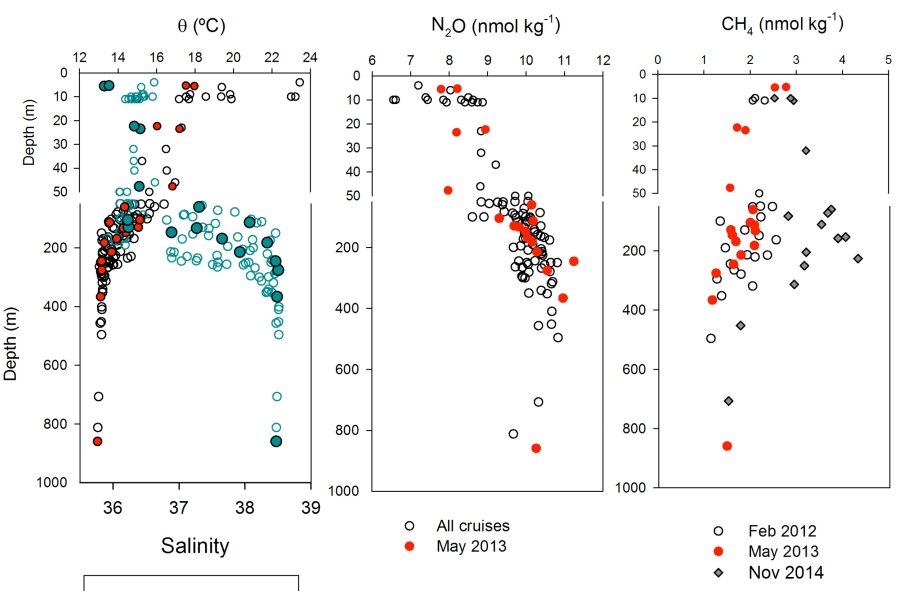

1126 

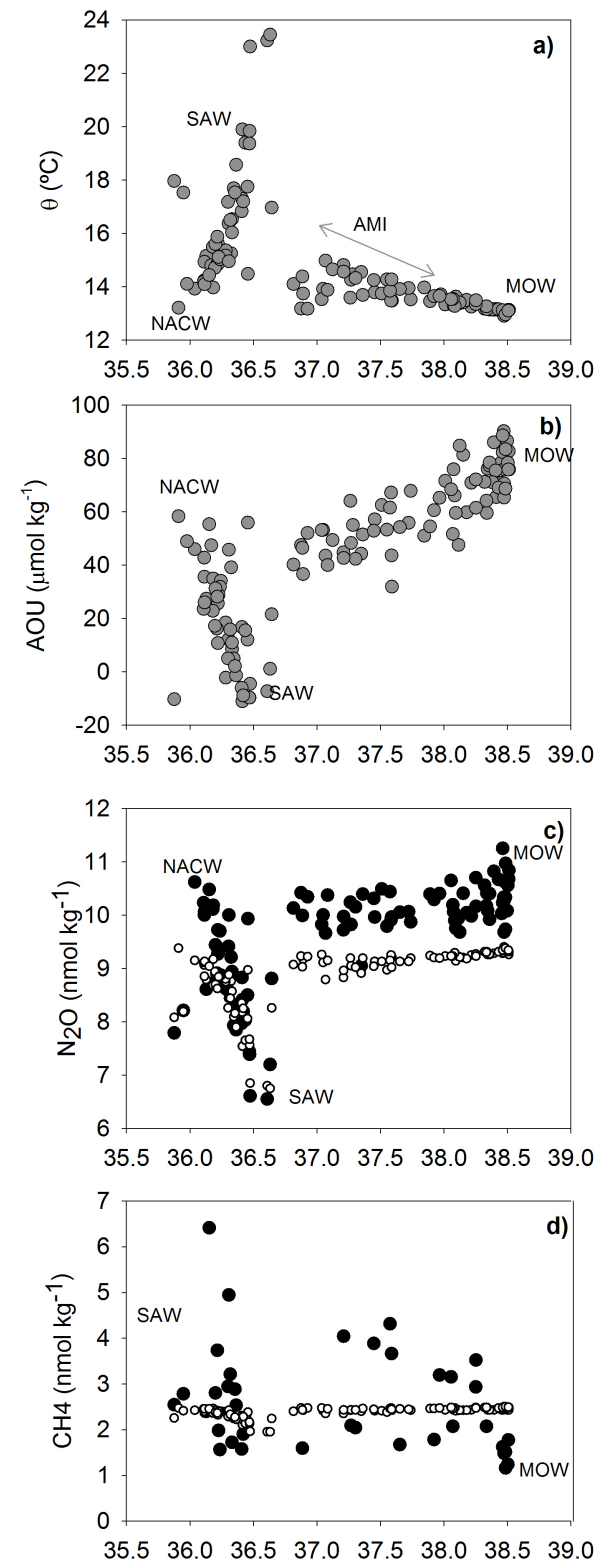

1127 Salinity

1128

1129 

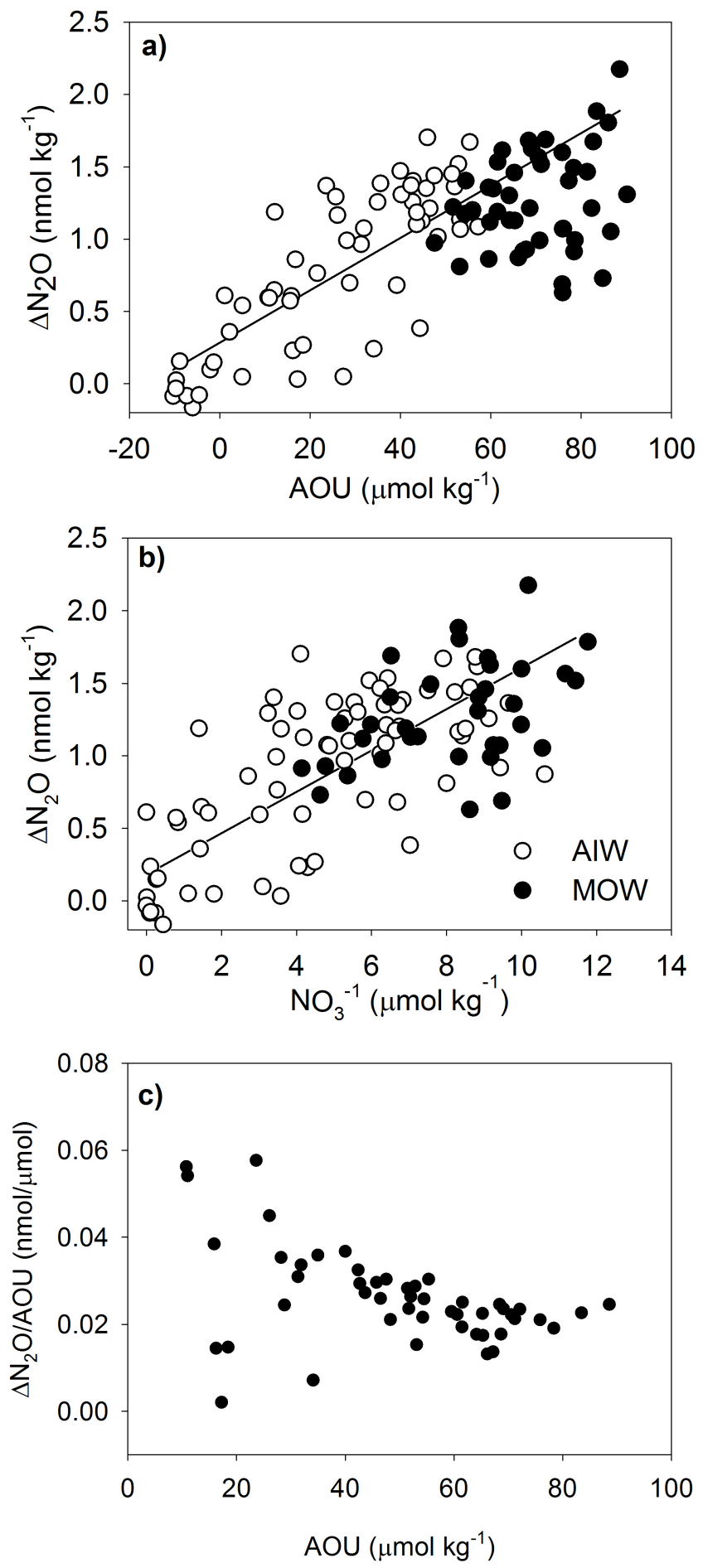

1131 

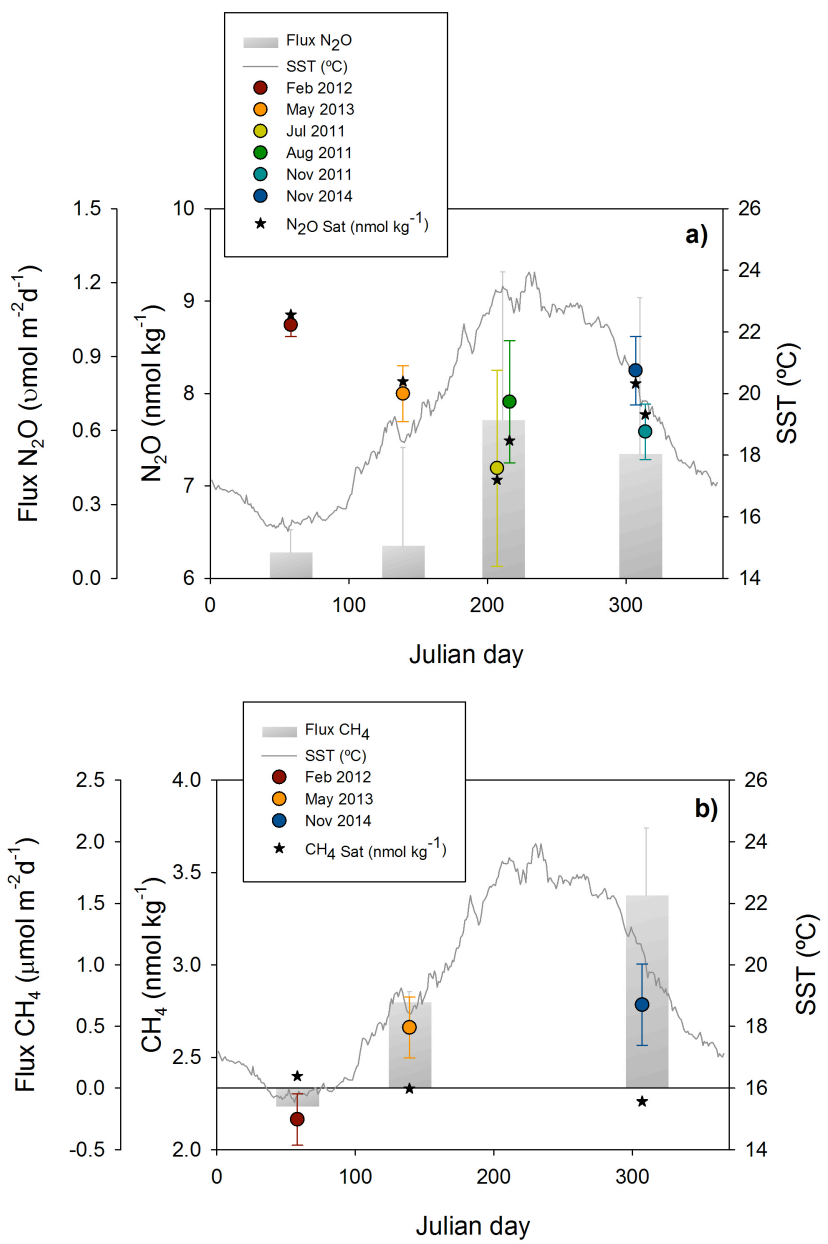

1132

1133

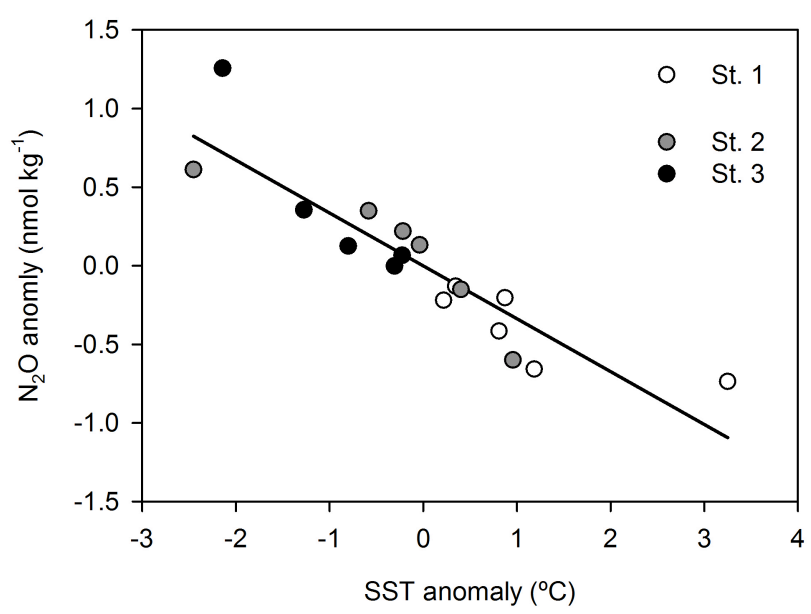

1134 